\title{
Anti-Photoaging and Potential Skin Health Benefits of Seaweeds
}

\author{
Ratih Pangestuti ${ }^{1}$, Kyung-Hoon Shin ${ }^{2} \mathbb{D}$ and Se-Kwon Kim ${ }^{2, *}$ \\ 1 Research and Development Division for Marine Bio-Industry, Indonesian Institute of Sciences (LIPI), \\ West Nusa Tenggara 83352, Indonesia; ratih.pangestuti@lipi.go.id \\ 2 Department of Marine Science and Convergence Engineering, College of Science and Technology, \\ Hanyang University, Gyeonggi-do 11558, Korea; shinkh@hanyang.ac.kr \\ * Correspondence: sknkim@pknu.ac.kr; Tel.: +82-31-400-5539
}

check for updates

Citation: Pangestuti, R.; Shin, K.-H.; Kim, S.-K. Anti-Photoaging and Potential Skin Health Benefits of Seaweeds. Mar. Drugs 2021, 19, 172. https://doi.org/10.3390/md19030172

Academic Editor: Chingfeng Weng

Received: 23 February 2021

Accepted: 20 March 2021

Published: 22 March 2021

Publisher's Note: MDPI stays neutral with regard to jurisdictional claims in published maps and institutional affiliations.

Copyright: (c) 2021 by the authors. Licensee MDPI, Basel, Switzerland This article is an open access article distributed under the terms and conditions of the Creative Commons Attribution (CC BY) license (https:// creativecommons.org/licenses/by/ $4.0 /)$.

\begin{abstract}
The skin health benefits of seaweeds have been known since time immemorial. They are known as potential renewable sources of bioactive metabolites that have unique structural and functional features compared to their terrestrial counterparts. In addition, to the consciousness of green, eco-friendly, and natural skincare and cosmetics products, their extracts and bioactive compounds such as fucoidan, laminarin, carrageenan, fucoxanthin, and mycosporine like amino acids (MAAs) have proven useful in the skincare and cosmetic industries. These bioactive compounds have shown potential anti-photoaging properties. Furthermore, some of these bioactive compounds have been clinically tested and currently available in the market. In this contribution, the recent studies on anti-photoaging properties of extracts and bioactive compounds derived from seaweeds were described and discussed.
\end{abstract}

Keywords: photoaging; seaweeds; skin; health; bioactive

\section{Introduction}

The skin is the largest organ of the integumentary system and one of the most complicated organs in the body. It has many function such as covering the internal organs, maintaining body temperature, preventing water loss, and acting as a protective physical barrier from the external (environment) stimulus, damaging pathogens, pollutions and ultraviolet (UV) radiation [1]. Though UV radiation (UVR) has many beneficial effects, the skin's prolonged exposure to UVR could be an aggressive factor for photoaging and mutations which cause cancer [2].

Melanocytes produce melanin as part of the skin's self-photoprotection, and possess biological properties (i.e., radical scavenging) [3,4]. The UVR directly and or indirectly induced the activation of complex signaling cascade in human skin [5]. This process begins by absorbing electromagnetic energy through cellular chromophores and then converting it into chemical energy. Furthermore, these energized chromophores react and produce generation of reactive oxygen species (ROS) which further leads to the activation of a wide range of transcription factors in skin cells such as activator protein-1 (AP-1) and nuclear factor kappa B (NF-kB) [6,7]. The AP-1 induces the upregulation of matrix metalloproteinases (MMP) such as collagenase-1 (MMP-1), stromelysin-1 (MMP-3), and gelatinase A (MMP-2), which specifically degrade connective tissues such as collagen and elastin and indirectly inhibit the collagen synthesis in the skin [8]. Furthermore, prolonged UVR exposure is considered as a leading cause of photoaging, and its symptoms could be characterized by wrinkles, loss of skin tone, pigmentation (hypo- or hyperpigmentation), rough skin, dryness, sallowness, deep furrows, severe atrophy, melanoma, and many others [9-11]. Therefore, it is important to provide adequate photoprotection to prevent photoaging and other skin disorders due to the deleterious effects of UVR. 
Various synthetic or semi synthetic materials have been used as anti-photoaging agents. However, these materials have limited use due to their instability and adverse side effects such as potential toxicity and potency to interfere with certain pathways of the multistage process of carcinogenesis [12]. In addition, consumers are conscious and demand more natural, green, and eco-friendly products with beneficial claims for the skin [13]. The increased demand of natural anti-photoaging products has led to a number of research works and innovation on nature-derived anti-photoaging agents.

Bioactive compounds from marine plants including seaweeds have proven to be a great source of novel materials for incorporating into anti-photoaging formulations [14,15]. The number, extraction, purification, and characterization of anti-photoaging compounds from marine sources are high and competitive compared to other marine floras such as sea grass, mangroves, and marine faunas (i.e., teripang or sea cucumber, sea star, sea urchin, and more). Furthermore, seaweed polysaccharides including fucoidan, laminarin, and carrageenan (Figure 1) showed potential anti-photoaging properties which were mediated by intra-cellular ROS scavenging activity in UV irradiated cells and in vivo models [16-19]. Other seaweed-derived materials such as mycosporine like amino acids (MAAs) are well known as the most potential natural UVA-absorbing molecules [13]. Moreover, their extracts are also continuously reported as potential anti-photoaging agents [20].
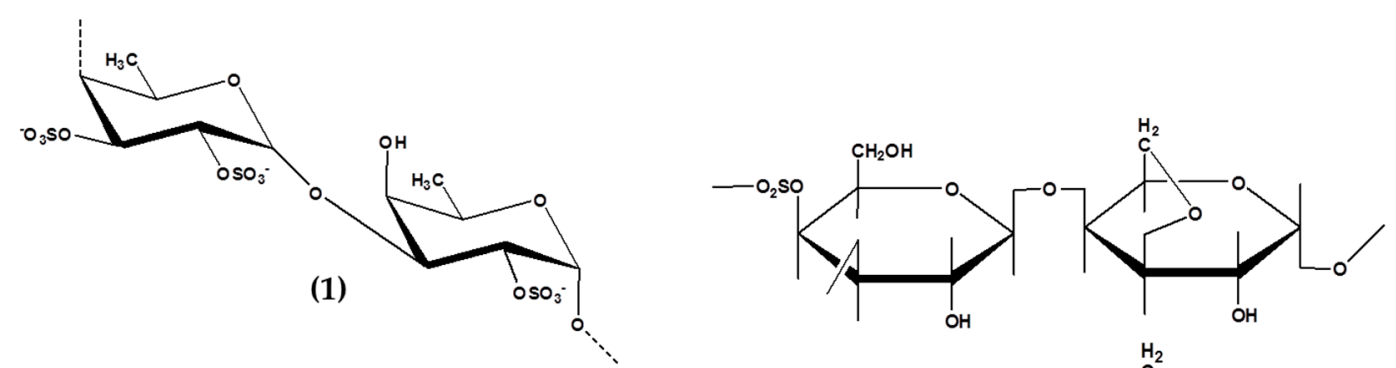

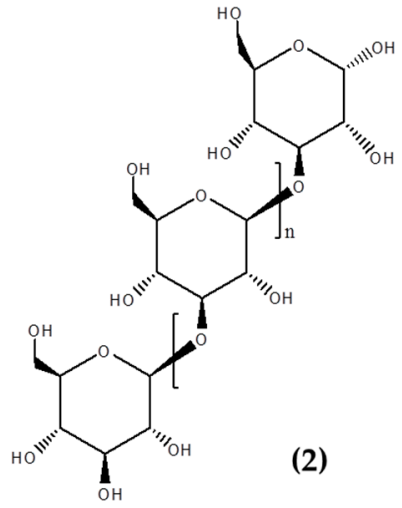

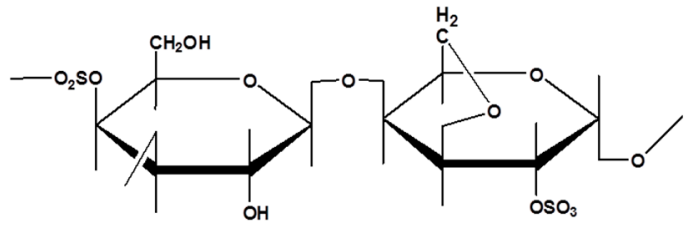

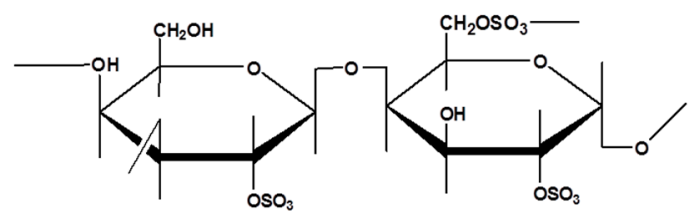

Figure 1. Chemical structure of seaweeds derived polysaccharides showed potential anti-photoaging properties. Fucoidan, 1; Laminarin, 2; Kappa-carrageenan, 3; iota-carrageenan, 4; and lambda-carrageenan, 5.

Therefore, bioactive compounds from seaweeds (Figures 1 and 2) have attracted great interest and are known for promoting distinct functional activities of interest for the development of anti-photoaging products. They exhibit great ability in targeting several key players linked to anti-photoaging properties such as radical scavenging activity, strong UV absorption, inhibit cell death, MMP-1, and other activities [14,21]. This review focused on the anti-photoaging potential of seaweed-derived bioactive compounds and extracts. The most relevant and up to date studies on anti-photoaging agents found in seaweeds and their biological roles were further summarized and discussed. In addition, the potential role they play in skincare and cosmetic products were also elaborated. 
<smiles>COC(C)=O</smiles><smiles>CCC1CC(N=CCO)=C(O)C(NCCO)C1</smiles><smiles>C=C1CC(CC)(CO)CC(NCO)=C1O</smiles>

(3)<smiles>CCC1(C)CC(O)=C(O)C(N=C2CC(CC)(CC)CC2NCCO)C1</smiles>

(4)<smiles>CCCNC1=C(O)C(=NCC)CC(O)(CC)C1</smiles>

(5)

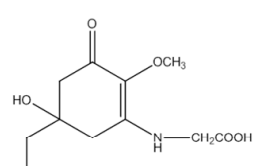

(6)<smiles>Oc1cc(O)cc(O)c1</smiles>

(7)<smiles>Oc1cc(O)cc(Oc2c(O)cc(O)cc2Oc2c(O)cc(O)cc2O)c1</smiles>

(8)<smiles>Oc1cc(O)cc(Oc2c(O)cc(O)c3c2Oc2c(O)cc4oc5cc(O)cc(O)c5c4c2O3)c1</smiles>

(9)<smiles>Oc1cc(O)cc(Oc2c(O)cc(O)c3c2Oc2cc(Oc4c(O)cc(Oc5c(O)cc(O)c6c5Oc5c(O)cc(O)cc5O6)cc4O)cc(O)c2O3)c1</smiles>

Figure 2. Carotenoids, Mycosporine like amino acids and Phlorotannins from seaweeds showed potential anti-photoaging properties. Fucoxanthin, 1; Shinorine, 2; Palythine, 3; Porphyra-334, 4; Asterina-330, 5; Mycosporine-glycine, 6; Phloroglucinol, 7; Triphlorethol-A, 8; Fucofuroeckol-A, 9; and Dieckol, 10.

\section{Seaweeds Extracts as Potential Anti-Photoaging Agents}

Seaweeds are autotrophic organisms that are widely distributed and consist of a wide variety of species. Based on the pigment contents they can be classified into red, green, and brown seaweeds [22]. Furthermore, they are found in intertidal shores to a depth of $150 \mathrm{~m}$ and are highly exposed and susceptible to UVR. Therefore, to counteract and minimize photodamage induced by high UVR, seaweeds synthesize photoprotective materials.

The anti-photoaging activities of seaweed extracts have been demonstrated in various in vitro and in vivo models (Table 1). The activities were mainly mediated by antioxidant properties, radical scavenging activity, and UV absorbing capacity. Furthermore, many seaweed extracts, especially red types possess significant levels of anti-photoaging activities. However, little attention has been paid towards the anti-photoaging properties of green seaweed extracts. The aqueous extract of Halimeda incrassata and Caulerpa sp showed anti-photoaging activity in UVC-irradiated plasmid DNA and UVB irradiated mice, respectively $[23,24]$. Furthermore, more than 20 seaweed species belonging to Rhodophyceae and Phaeophyceae obtained from several countries including Spain, Chile, Ireland, South Africa, Argentina, and Tonga were tested [25]. Compared to others, three species belonging to Rhodophyceae; Macrocystis pyrifera, Porphyra columbina, Sarcothalia radula and Gigartina skottsbergii exhibited the highest photoprotective activity. The authors correlated this photoproetective activity with total phenolic contents (TPCs). However, it might also correlate with high MAA contents in Rhodophyceae. For example, Porphyra yezoensis (also known as laver) extract showed strong photoprotective activity on the UVB-irradiated human keratinocytes (HaCaT) cells. While laver extract showed absorbance spectrum characteristics of MAAs in red algae and contained high phenolic compounds [26], it also showed the absorbance spectrum characteristic of major MAAs including porphyra-334 or shinorine. 
Table 1. Anti-photoaging and mechanisms of various seaweed extracts.

\begin{tabular}{|c|c|c|c|c|c|c|c|}
\hline Class & Species & Origin & Extracts & Test & Functions & Mechanisms & Ref \\
\hline \multirow{8}{*}{ Rhodophyceae } & Solieria chordalis & France & $\begin{array}{l}\text { MeOH extract/CPC fractionation } \\
n \text {-heptane/EtOAc//MeOH/dW } \\
(19 / 1 / / 19 / 1 ; v / v)\end{array}$ & - & $\begin{array}{l}\text { Photoprotective } \\
\text { Antioxidant }\end{array}$ & $\begin{array}{l}\text { UV absorption } \\
\text { DPPH radical scavenging } \\
\text { activity }\end{array}$ & [29] \\
\hline & Porphyra umbilicalis & France & $\begin{array}{l}\text { Cosmetic formula ( } 5 \% \text { extract) with } \\
\text { Ginkgo biloba, vitamins }\end{array}$ & UVA/B-irradiated mice & $\begin{array}{l}\text { Cell renewal } \\
\text { Anti-apoptosis }\end{array}$ & $\begin{array}{l}\text { transepidermal water loss } \\
\text { (TEWL) and erythema index. } \\
\text { ( } \downarrow \text { ) p53 and caspase-3 }\end{array}$ & [28] \\
\hline & Gelidium amansii & Korea & $\begin{array}{l}\text { Mix with Cirsium japonicum; } \mathrm{MeOH} \\
\text { extract and fermentation }\end{array}$ & $\begin{array}{l}\text { UVB-irradiated HS } 68 \\
\text { DF\& SKH-1 } \\
\text { hairless mice }\end{array}$ & $\begin{array}{l}\text { Inhibit collagen } \\
\text { degradation; } \\
\text { wrinkle formation }\end{array}$ & $\begin{array}{l}(\uparrow) \text { type I pro-collagen; } \\
(\downarrow) \text { MMP-1; }-2 ;-9 ;-13\end{array}$ & [30] \\
\hline & Polyopes affinis & Korea & EtOH extract & UVB irradiated $\mathrm{HaCaT}$ & $\begin{array}{l}\text { Antioxidant } \\
\text { Anti-apoptosis } \\
\text { Photoprotective }\end{array}$ & $\begin{array}{l}(\downarrow) \text { intracellular ROS; }(\downarrow) \\
\text { superoxide radical } \\
(\downarrow) \text { hydroxyl radical; } \\
(\downarrow) \text { cellular damage } \\
\text { NA } \\
\text { Absorb UVB rays }\end{array}$ & [31] \\
\hline & Solieria chordalis & France & EtOAc; 2-OD and OE L-PCA extract & - & Photoprotective & $\begin{array}{l}\text { Absorb UVB rays } \\
\text { Protect synthetic chlorophyll sol. } \\
\text { from UVB }\end{array}$ & [32] \\
\hline & Polysiphonia morrowii & Korea & $80 \% \mathrm{EtOH}$ & UVB irradiated $\mathrm{HaCaT}$ & $\begin{array}{l}\text { Antioxidant } \\
\text { Anti-apoptosis }\end{array}$ & $\begin{array}{l}(\downarrow) \text { intracellular ROS; } \\
(\uparrow) \text { antioxidant enzyme } \\
(\downarrow) \text { TUNEL-positive cells and } \\
\text { DNA fragmentation }\end{array}$ & [33] \\
\hline & Chondracanthus tenellus & Korea & $80 \% \mathrm{EtOH}$ & UVB irradiated HaCaT & $\begin{array}{l}\text { Antioxidant } \\
\text { Anti-apoptosis } \\
\text { Photoprotective }\end{array}$ & $\begin{array}{l}(\downarrow) \text { intracellular ROS; }(\downarrow) \\
\text { superoxide radical } \\
(\downarrow) \text { hydroxyl radical; }(\downarrow) \text { cellular } \\
\text { damage } \\
\text { NA } \\
\text { Absorb UVB rays }\end{array}$ & [34] \\
\hline & Bonnemaisonia hamifera & Korea & $80 \% \mathrm{EtOH}$ & UVB irradiated HaCaT & $\begin{array}{l}\text { Antioxidant } \\
\text { Anti-apoptosis } \\
\text { Photoprotective }\end{array}$ & $\begin{array}{l}(\downarrow) \text { intracellular ROS; }(\downarrow) \\
\text { superoxide radical } \\
(\downarrow) \text { hydroxyl radical } \\
(\downarrow) \text { TUNEL-positive cells and } \\
\text { DNA fragmentation } \\
\text { Absorb UVB rays }\end{array}$ & [35] \\
\hline
\end{tabular}


Table 1. Cont

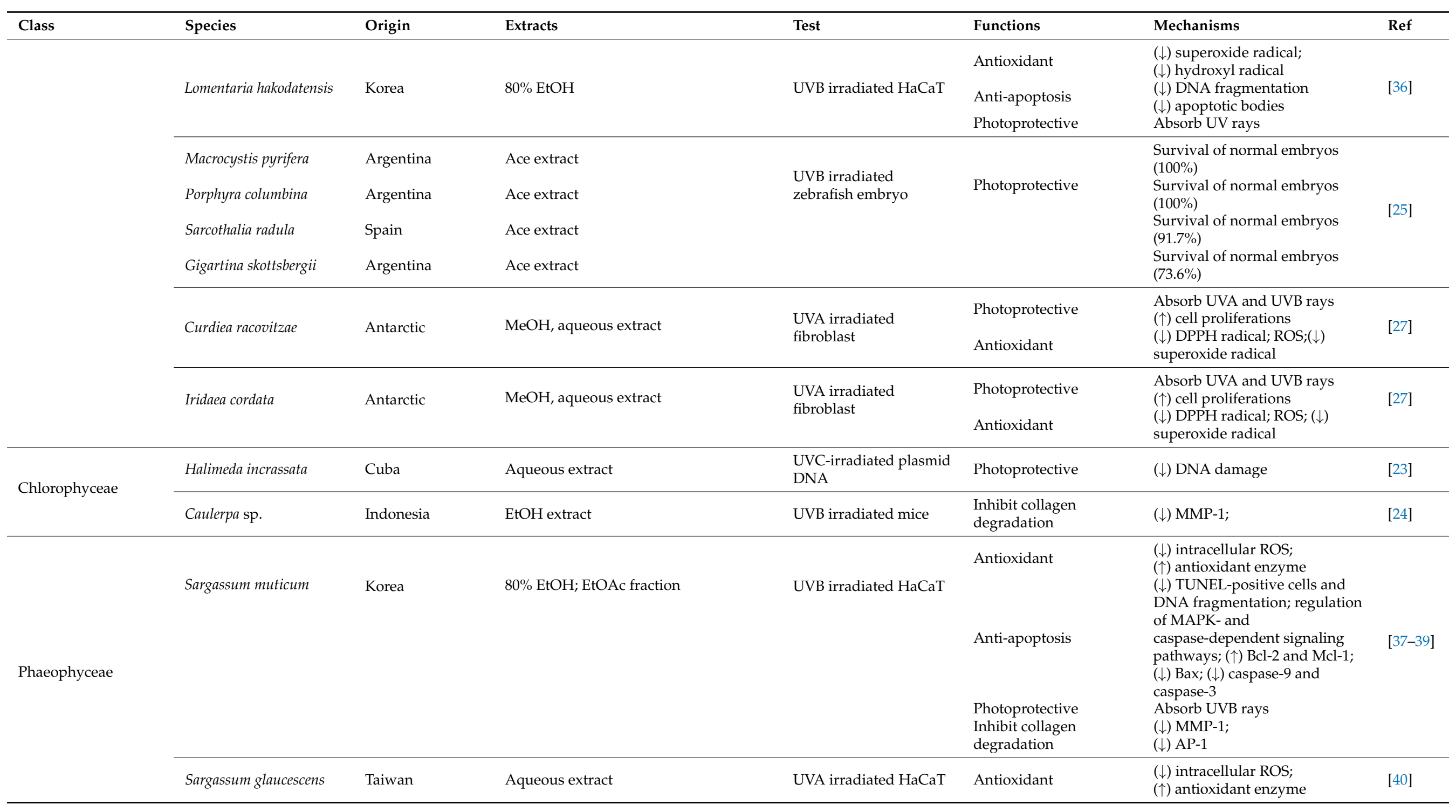


Table 1. Cont.

\begin{tabular}{|c|c|c|c|c|c|c|c|}
\hline Class & Species & Origin & Extracts & Test & Functions & Mechanisms & Ref \\
\hline & Sargassum cristafolium & Indonesia & EtOH extract & $\begin{array}{l}\text { UVA irradiated HeLa; } \\
\text { BALBL/c mice }\end{array}$ & Photoprotective & $\begin{array}{l}\text { Absorb UVA rays; }(\downarrow) \text { cellular } \\
\text { damage }\end{array}$ & [41] \\
\hline & Fucus spiralis & Portugal & $\begin{array}{l}\text { EtOH;Cyclohex; EtOAc; Et2O; aqueous } \\
\text { extract; }\end{array}$ & UVB irradiated HaCaT & $\begin{array}{l}\text { Photoprotective } \\
\text { Antioxidant }\end{array}$ & $\begin{array}{l}\text { Absorb UVA; UVB; UVC rays } \\
(\downarrow) \text { intracellular ROS; } \\
(\uparrow) \text { antioxidant enzyme }\end{array}$ & [20] \\
\hline & Mazzaella laminarioides & Chile & Ace extract & $\begin{array}{l}\text { UVB irradiated } \\
\text { zebrafish embryo }\end{array}$ & & $\begin{array}{l}\text { Survival of normal embryos } \\
(91.7 \%)\end{array}$ & [25] \\
\hline & Undaria crenata & Korea & $80 \% \mathrm{EtOH}$ & UVB irradiated HaCaT & $\begin{array}{l}\text { Antioxidant } \\
\text { Anti-apoptosis } \\
\text { Photoprotective }\end{array}$ & 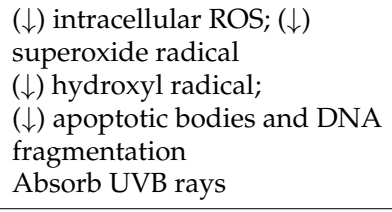 & [42] \\
\hline & Carpomitra costata & Korea & $80 \% \mathrm{EtOH}$ & UVB irradiated HaCaT & $\begin{array}{l}\text { Antioxidant } \\
\text { Anti-apoptosis }\end{array}$ & $\begin{array}{l}(\downarrow) \text { intracellular ROS; }(\downarrow) \\
\text { superoxide radical } \\
(\downarrow) \text { hydroxyl radical; }(\uparrow) \\
\text { antioxidant enzyme } \\
(\uparrow) \text { Bcl-2; }(\downarrow) \text { Bax }(\downarrow) \text { caspase-9 } \\
\text { and caspase-3 }\end{array}$ & [43] \\
\hline
\end{tabular}

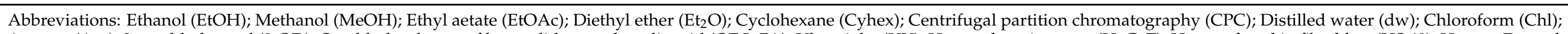

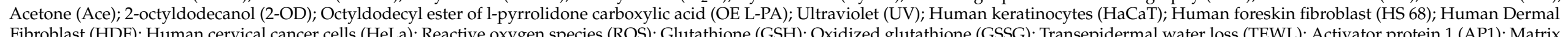

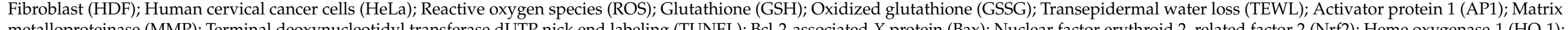
not available (NA); Down-regulated, decreased $(\downarrow)$; Up-regulated, increased $(\uparrow)$. 
Recently, the anti-photoaging properties of two Antarctic red seaweeds, Curdiea racovitzae and Iridaea cordata, have been described [27]. Both red seaweeds extract contains high concentrations of MAAs (palythine, asterina-330, and shinorine). Meanwhile, the total MAAs content of C. racovitzae and I. cordata are 150.17 and 60.78 ( $\mu$ g MAAs/mg extract), respectively. Furthermore, when compared with I. cordata, C. racovitzaei showed better photoprotective properties which might be correlated with higher MAAs contents. It also showed better ROS scavenging activity than quercetin and Helioguard $365^{\circledR}$ (anti-aging product containing MAAs Porphyra-334 and Shinorine; Mibelle Biochemistry, Switzerland). These red Antarctic seaweeds showed great potential for being developed as antiphotoaging agents.

The UV filters could be used in skincare and cosmetic products to protect the skin from harmful effects of UVR. Currently, many commercial UV filter products not only contain synthetic or semi synthetic UV filters, but they are also complemented with extracts and bioactive compounds from natural resources. In addition, products complemented with natural anti-photoaging agents are more effective in overcoming the undesirable effects of UVR. For example, the combination of Porphyra umbilicalis extracts, vitamins and Ginkgo biloba were able to improve the photoprotective performance of sunscreens, thereby preventing UVR-induced photodamage [28]. Therefore, seaweed extract could be added to anti-photoaging and sunscreen formulations in order to prevent oxidative stress and improve the absorption spectra of UV filters.

\section{Seaweed Compounds as Potential Sources of Anti-Photoaging Agents}

Seaweeds are heavily loaded with potential reservoirs of bioactive compounds such as polysaccharides, MAAs, natural pigments, phenolic compounds, proteins, peptides, and others. Previous studies have also investigated the anti-photoaging properties of bioactive compounds from seaweeds. In addition, further research has been carried out on the most studied seaweed-derived bioactive compounds and extracts as potential anti-photoaging agents.

\subsection{Polysaccharides Rich Extract}

The photoprotective activity of polysaccharides rich extract from brown seaweeds (Hizikia fusiforme, Sargassum fusiforme, Sargassum vachellianum, and Ecklonia maxima) was investigated and monosaccharide analysis showed that most of its rich extract contains sulfate group and a high amount of fucose (43.20 to $53.53 \%$ ) (Table 2). In addition, it was found that fucose-containing sulfated polysaccharides possessed various bioactivities and most of the polysaccharides rich extract were able to inhibit ROS production and down regulated MMP expression (especially MMP-1) [21,45-49]. This suggests that the anti-photoaging activity of polysaccharides rich extract from brown seaweeds was mainly mediated through antioxidant and MMP inhibitory activity.

The anti-photoaging properties of two fucoidan-rich seaweed extracts from Undaria pinnatifida and Fucus vesiculosus have been demonstrated. Both brown seaweeds extracts showed inhibitory activity against enzymes related to skin aging process. Clinical testing showed that both extracts were able to protect skin from UVR and wrinkle depth reduction. In addition, F. vesiculosus extract which contain polysaccharides and high polyphenol demonstrated additional efficacy in antioxidant and skin brightening benefits [50]. In addition, the mixture of fucose and rhamnose in skincare formulation has been claimed to inhibit skin ageing process [51].

Polysaccharides rich extracts from brown seaweeds are potentially developed as antiphotoaging agents in skincare or cosmetic products. Furthermore, when added in skincare or cosmetic products formulations, they improved the efficacy and maintained the skin in good condition especially due to their moisturizing properties. It is believed that some polysaccharides might also improve the stability and sensorial properties of cosmetic and skincare products. 
Table 2. Composition of seaweed rich polysaccharides extract showing anti-photoaging activity.

\begin{tabular}{lllll}
\hline Algae Source & Hizikia fusiforme & Sargassum fusiforme & Sargassum vachellianum & Ecklonia maxima \\
\hline Carbohydrate (\%) & NA & 58.10 & 53.51 & 69.37 \\
Sulfated & 63.56 & NA & NA & NA \\
polysaccharide (\%) & NA & 13.18 & 12.32 & 10.51 \\
Sulfated group (\%) & 17.37 & 5.90 & 3.5 & NA \\
Xylose (\%) & 23.15 & 18.40 & 9.3 & NA \\
Galactose (\%) & NA & 1.50 & 2.20 & NA \\
Glucose (\%) & 53.53 & 43.20 & 49.5 & NA \\
Fucose (\%) & NA & 3.50 & NA & NA \\
Rhamnose (\%) & NA & 18.50 & NA & NA \\
Fructose (\%) & NA & 9 & 11.2 & NA \\
Mannose (\%) & NA & 15.35 & 1.01 & NA \\
Glucuronic acid (\%) & {$[46,47]$} & {$[48]$} & {$[21]$} & [49] \\
\hline
\end{tabular}

\subsection{Fucoidans}

Fucoidans, sulfated polysaccharides, have been isolated from different brown seaweeds species. These compounds have attracted great interest in the food and cosmetic industries [16]. Furthermore, there are many studies that focused on the isolation, characterization, and medicinal values of fucoidans and the anti-photoaging properties of fucoidan.

The antioxidant activity of fucoidan has been determined by several radical scavenging methods and the most common are 1,1-diphenyl-2-picryl hydrazil (DPPH), superoxide anion, and hydroxyl radical scavenging assays. Fucoidan have exhibited both primary (chain-breaking antioxidants) and secondary (radical scavengers) antioxidants. The primary antioxidant potential of fucoidan is characterized by its ability to react directly with free radicals and convert them to more stable non-radical products [52-54]. Furthermore, the strong secondary antioxidant potential of fucoidan extracted from Sargassum binderi, Sargassum spp, and Undaria pinnatifida has been reported [55-57]. Its antioxidant activities are strongly related with sulfate content and molecular weight (MW). However, low molecular weight (LMW) fucoidan has shown more antioxidant potentials compared to synthetics antioxidant (Butylated hydroxyanisole; BHA) and higher MW fucoidan. Koh et al. (2019) suggested that the sulfate groups in the LMW fucoidan are more accessible compared to the ones with high molecular weight (HMW), thereby resulting in remarkably higher secondary antioxidant activity.

The photoprotective activity of fucoidan has been studied using UVB irradiated HaCaT and human foreskin fibroblast (HS 68) cells, zebrafish, and in vivo models [19,58-67]. The earliest study on the photoprotective activity of fucoidan was carried out by Kim et al. in 2008. They demonstrated its photoprotective activity in UVB-irradiated HS 68 cells via MMP-1 inhibition and ERK pathways [58,60]. Furthermore, the photoprotective activity of fucoidan from Hizikia fusiforme was observed in UVB-induced photodamage in human dermal fibroblasts (HDF) cells and zebrafish models. Its treatment significantly inhibited collagenase and decreased the intracellular ROS levels. Furthermore, it significantly inhibited intracellular collagenase, reduced the expression of MMP, and improved collagen synthesis in UVB-irradiated HDF [68]. The summary of the potential photoprotective activity of fucoidan is shown in Figure 3. Fucoidan is extensively explored for its photoprotective properties and being isolated from several brown seaweed species such as Costaria costata, Fucus evanescens, Sargassum hemiphyllum, Sargassum horneri, Sargassum siliquastrum, Ecklonia cava, Saccharina japonica, and Hizikia fusiforme. The biological activities are affected by many factors such as seaweed species, MW, purity, sugar composition, sulfation degree, co-extracted impurities, glycosidic linkage, and branching site [69]. In addition, it was found that the bioecology and harvesting months/seasons also influenced the composition and biological activities [70]. Mak et al. (2013) studied the monthly variations of fucoidan content in $U$. pinnatifida and it was found that the sporophyll part of $U$. pinnatifida consis- 
tently contained the highest amount compared to the frond part. Furthermore, it was found that the sporophyll maturation of $U$. pinnatifida strongly affected the fucoidan content and composition [70].

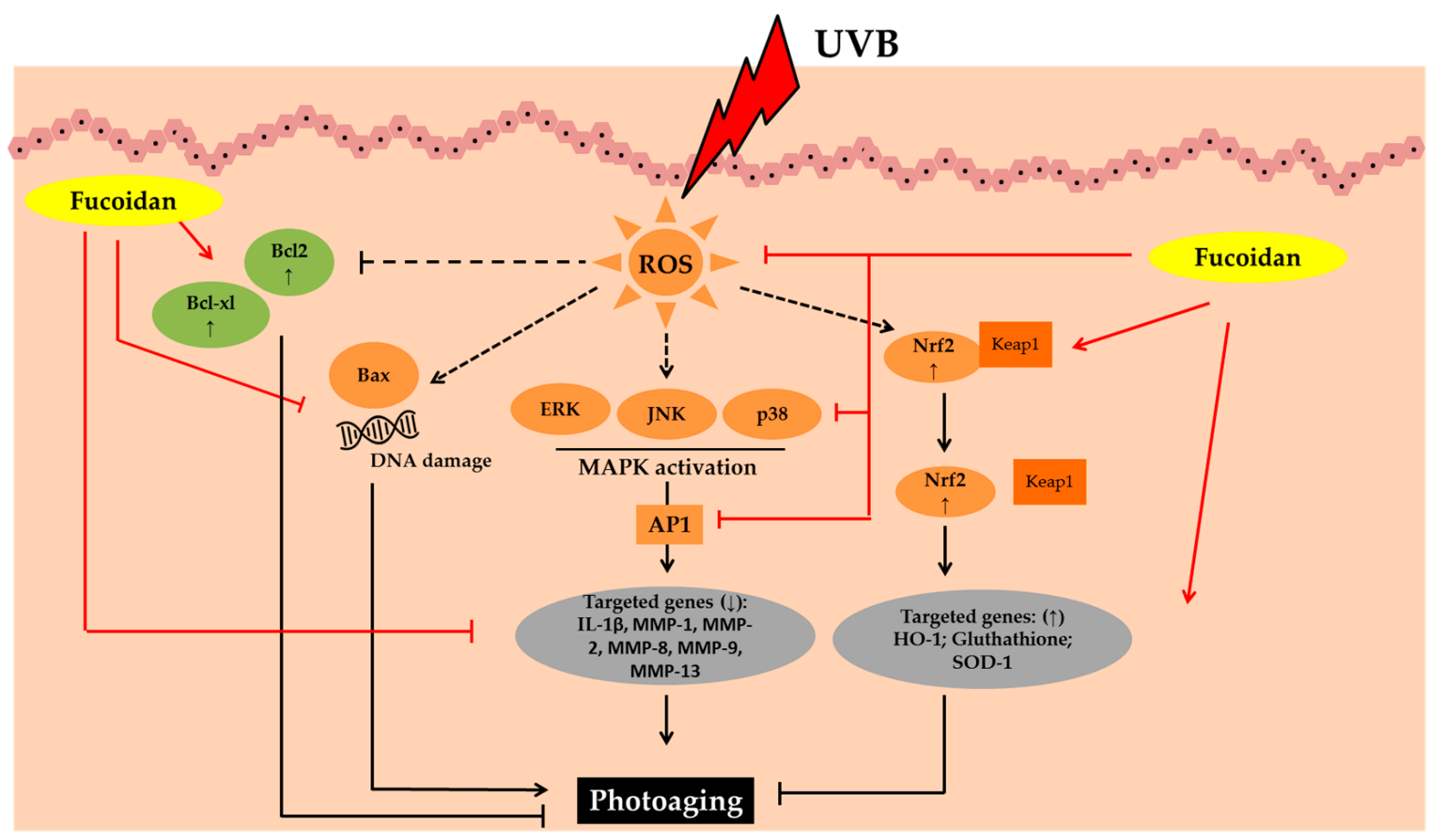

Figure 3. Photoprotective activity of fucoidan. Abbreviations: B-cell lymphoma-2 (Bcl-2), B-cell lymphoma-extra-large (Bcl-xL), Bcl-2-associated X protein (Bax), Reactive oxygen species (ROS), Mitogen-activated protein kinases (MAPK), c-JUN N-terminal kinase (JNK), Extracellular signal-regulated kinase (ERK); Activator protein 1 (AP1), interleukin-1 $\beta$ (IL-1 $\beta$ ), Matrix metalloproteinase (MMP); Nuclear factor erythroid 2-related factor 2 (Nrf2), Kelch Like ECH Associated Protein 1 (Keap1), Heme oxygenase-1 (HO-1);Superoxide dismutase 1 (SOD-1); Down-regulated, decreased ( $\downarrow$ ); up-regulated, increased $(\uparrow)$.

Generally, this polysaccharides contains sulfate, fucose as the main sugar, uronic acids, acetyl groups, protein, and other monosaccharides (such as mannose, glucose, galactose, xylose, and rhamnose) [71,72]. The structures and monosaccharide compositions of fucoidans from different brown algae sources vary from different species. Recently, Ponce et al., (2020) provided a comprehensive study on the compositional data of fucoidans from different brown seaweeds species. Its monosaccharide composition is strongly related with taxonomic classification and an example includes polysaccharides extracted from the genus Fucus which are classified as being rich in fucose ( $>70 \%$ of monosaccharides). Meanwhile, in order Laminariales, the presence of sulfated galactofucans with high galactose content is almost equal to the fucose content [72]. The composition and sulfation degree of fucoidan is strongly affected by extraction and purification methods. Therefore, there is a need to develop suitable extraction techniques to maintain its composition and sulfation pattern in order to obtain the desired bioactivity $[73,74]$.

Lower molecular weight has been reported to enhanced the biological activity of fucoidan [16]. Therefore, in order to obtain LMW and stronger bioactivities; chemical, radical, acidic, and enzymatic hydrolysis are generally used. Previous studies have shown that treatment with LMW fucoidan shows stronger photoprotective activity than HMW [62-64]. Hwang et al. (2017) provided detailed a extraction process and characterization of photoprotective activity of HMW, LMW, desulfated, and acetylated fucoidan isolated from S. hemyphyllum (Table 3) [62]. Furthermore, LMW fucoidan showed stronger protection against UVB-induced HS 68 cells. These results suggest that its fucose content, sulfation, and MW play an important role in photoprotective activity. Supporting these results, Kim et al. (2018) stated that LMW fucoidan treatment inhibits photoaging by enhance antiox- 
idant and anti-inflammatory activities and inhibiting extracellular matrix degradation in UVB-irradiated HR-1 (hairless) mice. It is mostly absorbed prior to UVB irradiation. Therefore, it is assumed that LMW fucoidan may involve in photoprotective effects rather than UV filtering. The LMW fucoidan extracted from $S$. horneri showed a stronger photoprotective activity compared to HMW in UVB-irradiated HaCaT cells [64].

Table 3. Sulfate, fucose, and average molecular weight of fucoidan showing photoprotective activity.

\begin{tabular}{ccccc}
\hline Algae Source & S. hemiphyllum & S. hemiphyllum & E. cava & S. horneri \\
\hline Fucose & $208.2 \pm 2.3(\mu \mathrm{mol} / \mathrm{g})$ & $210.9 \pm 3.3(\mu \mathrm{mol} / \mathrm{g})$ & NA & $37.43 \%$ \\
Sulfate $(\%)$ & $40.1 \pm 0.9$ & $38.9 \pm 0.4$ & NA & $28.01 \pm 0.50 \%$ \\
Average MW $(\mathrm{kDa})$ & 270 & 0.8 & $\sim 8$ & 60 \\
Ref & {$[62]$} & {$[62]$} & {$[63]$} & {$[64]$} \\
\hline
\end{tabular}

Abbreviations: Molecular Weight (MW); Kilodalton (kDa).

Pozharitskaya et al. (2019) investigated the pharmacokinetics of fucoidan after topical application in rats. It was found that ointment contains 15\% fucoidan are distributed into the skin, striated muscle, and plasma with area under concentration-time curve for topical dose $(\mathrm{AUC})_{0-48}=0.94 \mu \mathrm{g} \cdot \mathrm{h} / \mathrm{g}, 2.22 \mu \mathrm{g} \cdot \mathrm{h} / \mathrm{g}$, and $1.92 \mu \mathrm{g} \cdot \mathrm{h} / \mathrm{mL}$, respectively [75]. The longest half-life for fucoidan was observed in plasma, striated muscle and skin. In addition, its accumulation in plasma was not observed after repeated topical applications of $100 \mathrm{mg} / \mathrm{kg}$ for five days. Collectively, it may be assumed that topical treatment with cream containing fucoidan have efficacy and safety benefits with little concern of accumulation and toxicity. In addition, these results suggest the potential of fucoidan as an anti-photoaging agent in skincare and cosmetic industries.

\subsection{Carrageenans}

Carrageenans are natural polysaccharides extracted mainly from red seaweeds (i.e., Eucheuma spp, Chondrus crispus (Irish moss), and Gigartina stellate). They are joined by $\alpha-1,3$ and $\beta-1,4$ glycosidic linkage by alternate units of $d$-galactose and 3,6-anhydrogalactose [76]. Twenty percent of carrageenan production are used in pharmacy, skin care, and cosmetics products, and this is due to their unique physical functional properties (i.e., thickening, gelling, emulsifying, and stabilizing properties) [77]. The tree main types of commercially available carrageenan include kappa ( $\mathrm{K}$; forms strong, rigid gels in the presence of potassium ions), iota ( $\mathrm{l}$; forms soft, clear, and elastic gels in the presence of calcium ions) and lambda ( $\lambda$; does not form gel and normally used to thicken dairy products) [17].

In addition to their thickening and gelling properties, carrageenans have also shown potential antioxidant activities. De Souza et al. (2007) tested the antioxidant activity of $\kappa, l$ and $\lambda$ carrageenan and based on radical scavenging assay, $\lambda$ carrageenan had better results $[78,79]$. Furthermore, it was found that the degradation into carrageenan oligosaccharides enhanced its antioxidant activity [80]. Previous studies have shown that polysaccharides with LMW had stronger antioxidant activity compared to HMW polysaccharides. These activities may be related to the ability of LMW polysaccharides to have more reductive hydroxyl group terminals which further affect the ability to accept and eliminate free radicals. In addition Sun et al. (2015) reported that the antioxidant activities of carrageenan oligosaccharides could be related to the sulfate group, the degree of polymerization, the reduction of sugar, and the structure of reducing terminus [81].

Thevanayagam et. al. (2013) stated that the photoprotective effects of $k_{-}, \mathrm{l}-$ and $\lambda$ carrageenan in UVB-irradiated HaCaT cells [82]. All carrageenan types tested in their study showed significant protection against detrimental effects of UVB-induced apoptosis in $\mathrm{HaCaT}$ cells and scavenge free radicals. In addition, many studies have investigated the antioxidant activities of carrageenans [80,81,83,84].

In addition, the anti-photoaging activity of carrageenan also correlates with the modulations of inflammatory responses. These polysaccharides are able to induce the activation of proinflammatory mediators such as of tumor necrosis factor (TNF)- $\alpha$, interleukin (IL)- 6 , 
IL-1 $\beta$, inducible nitric oxyde synthase (iNOS), and cyclooxygenase-2 (COX-2) [85]. Furthermore, Tripp et al. (2003) found that COX-2 expression is an important factor for keratinocyte survival and proliferation after acute UV irradiation. The inhibition of COX-2 expression has been demonstrated to reduce epidermal keratinocytes proliferation [86]. Therefore, it is believed that the modulation of inflammatory responses and antioxidant activities of carrageenan may play an important role in their anti-photoaging activity. Purwaningsih et al. (2015) formulated a sunscreen cream with carrageenan and black mangrove fruit (Rhizopora mucronata). It was found that a sunscreen formula containing $0.5 \%$ carrageenan and $1 \%$ R. mucronata extract showed high photoprotective properties compared to other formulas tested in their study [87].

The photoprotective activities of carrageenan reported in previous study might reflect its new potential in skin care and cosmetic industries rather than just being used as an excipient. There are numerous advantages of these polysaccharides over other bioactive substances, including relatively low production costs, safety, non-toxic properties, wide acceptability, suggesting carrageenan as a promising anti-photoaging candidate in the near future; however, further studies such as formulations in order to obtain the most optimum anti-photoaging properties are required.

\subsection{Laminarins}

Laminarins are storage polysaccharides extracted from brown seaweeds and composed of (1-3)- $\beta$-d-glucan with $\beta-(1-6)$ branching with different reducing endings either mannitol or glucose residues. Laminarin has been extracted from several brown algae species such as Eisenia bicyclis, Saccharina longicruris, Laminaria digitata, Laminaria hyperborean, Laminaria japonica, Sargassum mcclurei, Cystoseira barbata, and Durvillaea potatorum [88-91].

In vivo studies have shown the anti-photoaging potential of laminarin and an example is the study conducted by $\mathrm{Li}$ and colleagues (2013) which was based on the effect of laminarin on the activity of MMP-1 of photoaging skin in mice models. The laminarin treatment significantly increased the thickness of dermis, tissue inhibitor MMP-1 (TIMP-1) level, and decreased the expression and release of MMP-1 [92]. It also protected mouse dorsal skin from UVB induced photodamage [93]. Furthermore, it significantly increased collagen fibers in the dermis of the UVB treated ICR mice. Laminarin pretreatment provided photoprotection by decreasing oxidative stress and increasing antioxidant enzymes including superoxide dismutase (SOD)-1, SOD-2, glutathione peroxidase (GPx), and catalase (CAT). In addition, it also showed photoprotective properties in UVA-irradiated HDF, $\mathrm{HaCaT}$ and normal human epidermal keratinocytes (NHEK) cells [89]. Treatment with laminarin attenuates pro-inflammatory cytokines (IL-6) levels and basal ROS levels in HDF and NHEK cells at concentration of 1 and $10 \mu \mathrm{g} / \mathrm{mL}$.

Many studies have reported the enhanced antioxidant activity of LMW laminarin $[18,90,94-98]$. This encouraged Choi et al. (2011) to prepare LMW laminarin by gamma irradiation and the formation of carbonyl groups by gamma irradiation was observed. Carbonyl groups were mainly attributed to the enhanced antioxidative activity of laminarin $[95,96]$. However, Rajauria et al. (2021) found that the purification of laminarin which involve solvents and molecular weight cut-off (MWCO) filters reduced the antioxidant activity compared to the crude laminarin extract [94]. In addition, chemical modifications (i.e., sulfation, carboxymethylation, acetylation, phosphorylation, and benzoylation) have affected the antioxidant activity of polysaccharides to some extent. The chemical modifications of laminarin via carboxylation using dielectric barrier discharge, conjugation with gallic acid, and sulfation have also been reported. Analyses of the chemical composition of carboxylated laminarin (LMC), gallic acid-conjugated laminarin (LMG), and sulphated laminarin (LMS) yielded $11.7 \%$ carboxyl groups, $1.5 \%$ gallic acid, and $1.4 \%$ sulfate content, respectively. This chemically modified laminarin was tested against several antioxidant assays including total antioxidant, hydroxyl radical scavenging, superoxide radical scavenging, iron chelating, reducing power and copper chelating assays. It was 
reported that LMG showed better antioxidant activities compared to other chemically modified laminarin [98].

Interestingly, Sellimi et al. (2018) showed that the topical application of laminarinbased creams improved the wound healing process in rats by accelerating the collagen deposition and re-epithelization and protected the skin cells from oxidative stress [91]. It appears to be a promising skincare and cosmetic ingredients for anti-photoaging agents. However, treatments with laminarin at high concentration have decreased the metabolic activity in dermal fibroblasts and keratinocytes cells [89]. Therefore, in order to be applied in skincare and cosmetics, further study on laminarin solubility, efficacy evaluation, penetration capacity, half-life time in blood, and bioavailability of laminarin needs to be carried out.

\subsection{Phlorotannins}

Polyphenolic compounds are a class of secondary metabolites which are categorized into several classes according to the number of phenol rings and structural elements that bind them together [43]. Phlorotannins are class of polyphenol compounds found exclusively in brown seaweeds and synthesized via acetate-malonate pathway (also known as the polyketide pathway) [99]. Furthermore, they are also known as seaweeds-chemical defense agents. These bioactive compounds protect seaweeds against grazers, important components of seaweeds cell wall and are responsible for the absorption of UVR [100].

Phlorotannins have been extracted from different brown seaweed resources such as Ecklonia cava, Ecklonia stolonifera, Sargassum thunbergii, Hizikia fusiforme, Endarachne binghamiae, Laminaria sp., and Sargassum piluliferum (Table 4). Out of the total brown seaweed species, E. cava was found to contain more total phenol contents [101]. Compared to other phlorotannins isolated from E. cava, phlorogucinol showed stronger cytoprotective effects in UVB-irradiated $\mathrm{HaCaT}$ cells. Currently, the anti-photoaging properties of phloroglucinol are far more explored compared to other phlorotannins. Phloroglucinol showed strong antioxidant activities by inhibiting hydroxyl radical, superoxide radical, and intracellular ROS, and induced the expression of antioxidant enzymes by activating the nuclear factor erythroid 2 (NFE2)-related factor 2 (Nrf2)/ heme oxygenase-1 (HO-1) signaling. Milanovic and colleagues (2020) studied the antioxidant activity of phloroglucinol and 2,4,6-Trihydroxypyridine towards $\mathrm{HO}$ - radicals. The study showed that phloroglucinol is a more powerful antioxidant compared to 2,4,6-Trihydroxypyridine [102]. Furthermore, it was found that the electron-withdrawing effect of nitrogen was stronger than the electron donating effect of the $\mathrm{OH}$ groups in the molecule of 2,4,6-Trihydroxypyridine. The structure difference of 2,4,6-Trihydroxypyridine with phloroglucinol is the substitution of nitrogen atom in the aromatic ring of phloroglucinol. Therefore, chemical modifications may affect the scavenging capacity of phloroglucinol. In addition, many studies have showed that the anti-photoaging activity of phlorotannins is strongly related to their radical scavenging activity. The hydroxyl $(-\mathrm{OH})$ group bound to the aromatic ring donates electron and give it to a free radical or other reactive species. This underlies the inhibition of ROS and ROS-mediated damage on macromolecules, which in turn contributes to inhibiting the activation of the signal transduction pathways such as the NF- $\mathrm{kB}$, mitogen-activated protein kinase (MAPK) signaling pathway.

Phlorotannins represent great potency as active anti-photoaging substances by providing multiple actions such as antioxidant, anti-inflammatory, MMP-inhibition, and down-regulation of pro-apoptotic factors. Based on to a certain level of concentration, they do not exert any toxic effect, anticipating its potential use as safe anti-photoaging agents in skin care and cosmetic products. The other biological activity such as anti-microbial activity of phlorotannins shows potency of phlorotannins as natural preservatives in skincare and cosmetic products. Therefore, besides functioning as anti-photoaging agents, they also show great potential to be used as skincare and cosmetic agents with other potential skin benefit effects. 
Table 4. Phlorotannin extracted from brown seaweed with potential anti-photoaging activity.

\begin{tabular}{|c|c|c|c|c|}
\hline Phlorotannins & Seaweeds & Origin & Anti-Photoaging & Ref \\
\hline Eckol & $\begin{array}{l}\text { Ecklonia stolonifera; } \\
\text { Ecklonia cava }\end{array}$ & Korea & $\begin{array}{l}\text { Inhibit NF- } \mathrm{k} \text {, AP-1, } \\
\text { MMP-1 expression } \\
\text { Protect UVB-induced cell damage; } \\
\text { ( } \downarrow) \text { Pro-inflammatory mediators }\end{array}$ & {$[101,103,104]$} \\
\hline Dieckol & Ecklonia stolonifera & Korea & $\begin{array}{l}\text { Inhibit NF- } \mathrm{kB}, \mathrm{AP}-1 \text {, } \\
\text { MMP-1 expression } \\
\text { Protect UVB-induced cell damage; } \\
(\downarrow) \text { Pro-inflammatory mediators }\end{array}$ & [103-106] \\
\hline Phloroglucinol & Ecklonia cava & Korea & $\begin{array}{l}(\downarrow) \text { hydroxyl and superoxide } \\
\text { radical, } \\
\text { intracellular ROS; ( } \uparrow \text { SOD, GSH; } \\
\text { Activate Nrf2/HO-1 } \\
\text { Inhibit NF- } \mathrm{B}, \mathrm{MAPK} ; \\
\text { MMP-1 expression } \\
(\downarrow) \text { Bax; Caspase-3 } \\
(\downarrow) \text { Pro-inflammatory mediators }\end{array}$ & {$[101,107-111]$} \\
\hline Triphlorethol-A & Ecklonia cava & Korea & $\begin{array}{l}\text { Protect UVB-induced cell damage; } \\
(\downarrow) \text { intracellular ROS; } \\
\text { Inhibit MAPK; MMP-1 expression } \\
(\downarrow) \text { Caspase- } 3 \text { and -9 } \\
\text { Strong absorption in UVB spectra }\end{array}$ & {$[101,112,113]$} \\
\hline Eckstolonol & Ecklonia cava & Korea & Protect UVB-induced cell damage & [101] \\
\hline Diphlorethohydroxycarmalol & Ishige okamurae & Korea & $\begin{array}{l}\text { Inhibit MAPK; MMP-1; -2; -9 } \\
\text { expression } \\
\text { ( } \downarrow) \text { Pro-inflammatory mediators } \\
(\downarrow) \text { cellular damage }\end{array}$ & [114-116] \\
\hline Fucodiphlorethol G & Ecklonia cava & Korea & $\begin{array}{l}(\downarrow) \text { DPPH, intracellular ROS; } \\
\text { caspase-9 } \\
\text { UVB absorption }\end{array}$ & {$[117,118]$} \\
\hline
\end{tabular}

Abbreviations: Nuclear factor kappa-light-chain-enhancer of activated B cells (NF-kB); Activator protein 1 (AP1); matrix metalloproteinase (MMP); Ultraviolet B (UVB); Reactive oxygen species (ROS); Bcl-2-associated X protein(Bax) [119], Nuclear factor erythroid 2-related factor 2 (Nrf2); Heme oxygenase-1 (HO-1); superoxide dismutase 1 (SOD-1); Glutathione (GSH); Mitogen activated protein kinases (MAPK); Down-regulated, decreased $(\downarrow)$; Up-regulated, increased $(\uparrow)$.

\subsection{Mycosporine Like Amino Acids}

Mycosporine-like amino acids are LMW, water-soluble molecules that strongly absorb UVA and UVB; generally MW of MAAs are (<400 Da) [120]. These colorless LMW molecules are widely distributed in natures and could be found in many organisms such as phytoplankton, terrestrial lichens, cyanobacteria, coral, cnidarians, sponges, shrimp, sea urchins, starfish, clams, ascidians, and seaweeds [121]. Differing with photosynthetic pigments, MAAs is invoked to function as a passive shielding substances by dissipating the absorbed radiation energy in the form of harmless heat without generating photochemical reactions [122]. Their absorption maxima are around 310 to $360 \mathrm{~nm}$ depending on the molecular structure $[13,123]$. Based on the structural view, MAAs consists of cyclohexenimine ring conjugated with two amino acid, amino alcohol or amino group substituents [124].

Mycosporine-like amino acids are demonstrated as one of the strongest naturally occurring UVA-absorbing molecules [13]. Currently, they have been identified from more than 500 seaweed species $[125,126]$. Furthermore, when compared to other seaweed classes, the red category is an excellent source of MAAs. Sun et al. (2020) stated that in seaweeds, they are mainly distributed in orders Bangiales, Ceramiales, Gigartinales, and Gracilariales. In Table 5, information is provided on several MAAs present in seaweeds. Furthermore, during the last five years, a growing number of papers focusing on anti-photoaging properties of MAAs from seaweeds have been observed. 
Table 5. Mycosporine like amino acid extracted from different seaweed species.

\begin{tabular}{|c|c|c|c|c|c|c|c|c|c|c|c|}
\hline Species & Origin & PI & AS & SH & PR & Myc-gly & Usu+PI & PL & $\mathrm{CL}$ & Total & Ref \\
\hline $\begin{array}{c}\text { Ahnfeltiopsis devoniensis } \\
(\mathrm{mg} / \mathrm{g})\end{array}$ & Spain & NA & NA & 0.55 & NA & NA & NA & NA & NA & NA & [127] \\
\hline $\begin{array}{l}\text { Curdiea racovitzae } \\
(\mu \mathrm{g} / \mathrm{mg})\end{array}$ & Antarctic & 111.49 & 36.51 & 2.17 & NA & NA & NA & NA & NA & 150.17 & [27] \\
\hline Catenella repens $(\mathrm{mg} / \mathrm{g})$ & France & NA & NA & NA & NA & NA & NA & NA & 1.76 & NA & [128] \\
\hline $\begin{array}{c}\text { Catenella caespitosa } \\
(\mathrm{mg} / \mathrm{g})\end{array}$ & $\begin{array}{l}\text { Puerto } \\
\text { Rico }\end{array}$ & NA & NA & NA & NA & NA & NA & NA & 1.06 & NA & [128] \\
\hline Gelidium corneum (mg/g) & Spain & 0.13 & 0.47 & 0.1 & NA & NA & NA & NA & NA & NA & [127] \\
\hline $\begin{array}{l}\text { Gracilariopsis longissima } \\
(\mathrm{mg} / \mathrm{g})\end{array}$ & NA & NA & NA & NA & NA & NA & NA & NA & NA & 1.6 & [129] \\
\hline $\begin{array}{c}\text { Gracilaria birdiae }(\mathrm{mg} / 100 \\
\mathrm{g})\end{array}$ & Brazil & 14.67 & NA & 52.70 & 178.39 & NA & NA & NA & NA & 245.77 & [130] \\
\hline $\begin{array}{l}\text { Gracilaria caudate } \\
(\mathrm{mg} / 100 \mathrm{~g})\end{array}$ & Brazil & 34.55 & NA & 32.20 & 48.15 & NA & NA & NA & NA & 114.90 & [130] \\
\hline $\begin{array}{l}\text { Gracilaria domingensis } \\
(\mathrm{mg} / \mathrm{g})\end{array}$ & Brazil & 10.41 & 1.25 & 7.56 & 28.82 & NA & NA & 1.54 & NA & 49.59 & [130] \\
\hline $\begin{array}{l}\text { Hydropuntia cornea } \\
(\mathrm{mg} / \mathrm{g})\end{array}$ & NA & NA & NA & NA & NA & NA & NA & NA & NA & 0.8 & [129] \\
\hline Iridaea cordata $(\mu \mathrm{g} / \mathrm{mg})$ & Antarctic & 49.45 & 7.58 & 3.75 & NA & NA & NA & NA & NA & 60.78 & [27] \\
\hline $\begin{array}{l}\text { Palmaria palmata } \\
(\mu \mathrm{mol} / \mathrm{g})\end{array}$ & Japan & 2.964 & 0.078 & 0.155 & 1.900 & 0.276 & 0.276 & NA & NA & 5.372 & [131] \\
\hline Palmaria palmata $(\mathrm{mg} / \mathrm{g})$ & UK & 9.94 & 0.08 & 0.63 & 0.56 & NA & NA & 0.11 & NA & NA & [128] \\
\hline $\begin{array}{l}\text { Porphyra rosengurttii } \\
\qquad(\mathrm{mg} / \mathrm{g})\end{array}$ & Spain & 0.17 & 0.14 & 0.38 & 3.84 & NA & NA & NA & NA & NA & [127] \\
\hline
\end{tabular}

Abbreviations: Palythine (PI); Asterina-330 (AS); Shinorine (SH); Porphyra-334 (PR); Mycosporine-glycine (Myc-Gly); Usujirene (Usu); Palithynol (PL); Catenelline (CL); not available (NA).

The anti-photoaging activities of MAAs are not only mediated by their photoprotective activity by absorbing UVR, but also by strong antioxidant, radical scavenging, macromolecule damage-protection, anti-inflammatory, MMP inhibitor, and other potential anti-photoaging activities. Furthermore, the antioxidant activity of seaweeds derived MAAs such as porphyra-334, shinorine, asterina-330, palythine and mycosporine -glycine (Myc-Gly) have been tested in various assays. These include 2,2'-Azinobis-(3Ethylbenzothiazoline-6-Sulfonic Acid Assay (ABTS+) radical scavenging, $\beta$-carotene/ linoleate bleaching method, scavenging capacity of superoxide radicals, Oxygen Radical Absorbance Capacity (ORAC-fluorescein) Assay, ROS scavenging [127,132,133]. In general, MAAs showed strong antioxidant activities. However, the exact mechanisms are still unknown and further investigations need to be carried out on the antioxidant mechanisms of MAAs.

In addition, MAAs derived from seaweed also showed photoprotective activity in $\mathrm{HaCaT}$ cells by protecting DNA damage from UVB radiation [134]. Recently, it was demonstrated that Porphyra-334 and shinorine treatment activated Nrf2/Kelch-like ECHassociated protein 1 (Keap1) pathway. Porphyra-334 and shinorine first dissociated Nrf2 from Keap1. Increased mRNA expression of Nrf2 targeted genes encoding oxidative stress defense proteins prior and post UVR exposure were observed [135]. Treatment of shinorine and Porphyra-334 in UV irradiated mice was found to increase the expression of endogenous antioxidant (SOD, GSH-Px, CAT), and decrease malondialdehyde expression [136]. Seaweed-derived MAAs showed antioxidant properties through several functions which include strong UV absorption, protecting macromolecules damage, and antioxidant capacity.

Seaweeds-derived MAAs have also been tested for their anti-inflammatory properties in UV-irradiated HaCaT cells [137]. Porphyra-334 treatments suppressed COX-2 expression and one of the main cytotoxic mediators participating in the innate response in mammals [138]. In addition, Shinorine and Porphyra-334 treatment in LPS-stimulated macrophages cells showed potential anti-inflammatory properties. While MAAs treatment significantly suppressed the release of pro-inflammatory mediators which were mediated through NF-KB signaling pathway [139]. Supporting these results, Poprhyra-334 treatment in UV-irradiated mice also inhibited the activation of NF- $\mathrm{KB}$ and MAPK signaling 
pathways [140]. Furthermore, many intracellular signaling pathways are involved in inflammatory responses. However, NF- $\mathrm{kB}$ and MAPK are amongst the most important signaling molecules involved in inflammatory responses [141]. Collectively, these reports have showed MAAs as potential anti-inflammatory agents stimulated by UV-irradiation.

Collagen is the major structural protein of the extracellular matrix (ECM) that provides supportive framework to the cell and is responsible for strength, elasticity, and hydration of the skin. [142] Therefore, collagen and ECM play an important role in skin health, beauty, and aging. Porphyra-334 showed potential anti-photoaging properties by inhibiting MMP1 and MMP-3 levels. Treatment of Porphyra-334 in human dermal fibroblast cells increase ECM components, such as procollagen, type I collagen, elastin [132,143]. Porphyra-334 also showed an inhibition of advanced glycation end products (AGEs) [143]. The results indicated that treatment with Porphyra-334 maintains the structural integrity of collagen fibers by absorbing ultraviolet radiation. Therefore, Porphyra-334 showed great potential function in preventing skin photoaging.

Among other seaweed-derived MAAs, Porphyra-334 is the most studied MAAs. They have also been reported to down regulate caspase-3 protein expression in UV irradiated $\mathrm{HaCaT}$, suggesting another anti-photoaging properties were also mediated by the down-regulation of pro-apoptotic factors [134]. Suh et al. (2017) studied the expression profiling of Porphyra-334 modulated genes or microRNA (miRNAs) in response to UV-exposure and their functional networks. It was found that Porphyra-334 regulated Wnt (Wingless/integrase-1; related to UV-repressed genes) and Notch signaling pathways. Furthermore, it is assumed that Porphyra-334 protects cells from UV-induced photoaging through the comprehensive modulation of expression patterns of genes involved in UV-mediated biological processes [144].

Sunscreen cream containing $0.005 \%$ MAAs extracted from P. umbilicalis (nori) was found to neutralize photodamage caused by UVA radiation as efficiently as cream containing $1 \%$ synthetic UVA and $4 \%$ UVB filters [145]. Furthermore, the formulation of Porphyra-334 increased the photoprotective activity of sunscreen formula [146]. MAAs protects the skin cells by their ability to disperse harmful UV into heat that dissipates into the surroundings without forming reactive photoproducts. The treatment with MAAs was able to inhibit skin wrinkle depth, roughness, and elasticity. This suggests that MAAs are effective and potential anti-photoaging agents. In a recent article, it was found that sunscreen formulated with MAAs showed the same Sun Protecting Factor (SPF) and UVBBiological Effective Protection Factors (BEPFs) as reference sunscreens but slightly lower UVA-BEPFs [147].

\subsection{Carotenoids}

Carotenoids are essential natural pigments along with chlorophylls in photosynthetic organisms, bacteria, and fungi. Furthermore, these tetraterpene pigments are involved in photosynthesis and photoprotection. Carotenoids can be classified into two broad groups, namely carotenes (contain no oxygen) and xanthophylls (oxygenated derivatives of carotenes) [148]. In 2018, around 850 carotenoids were been found, and the number is still increasing [149]. Among carotenoids isolated from seaweeds, fucoxanthin is a major xanthophyll with diverse biological functions. These carotenoids represent more than $10 \%$ of total carotenoids.

The anti-photoaging function of fucoxanthin has been investigated by many studies (Figure 4). As a consequence of UVB irradiation, cells face an intense oxidative reaction that gives rise to photodamage and photoaging. Furthermore, fucoxanthin isolated from Korean brown seaweeds Sargassum siliquastrum showed photoprotective properties in UVB-irradiated human fibroblast. A $24 \mathrm{~h}$ pretreatment with fucoxanthin $(50-250 \mu \mathrm{M})$ were able to reduce oxidative stress via ROS scavenging activity and counteract UVBinduced cell damage in dose-dependent manner [150]. Furthermore, fucoxanthin also showed remarkable ROS scavenging activity in UVB-irradiated mice and HaCaT and HDF cells [151-153]. It showed strong antioxidant activity due to its singlet oxygen quenching 
$\left({ }^{1} \mathrm{O}_{2}\right)$ and ROS scavenging effects. From the structural view, fucoxanthin has a unique unusual allenic bond and 5,6-monoepoxide in its molecule which plays an important role in ROS scavenging activity [22]. In addition, functional groups in the terminal ring of fucoxanthin also have an effect in their antioxidant activity. The electron-rich status of fucoxanthin makes this carotenoid an effective radical scavenger [154].
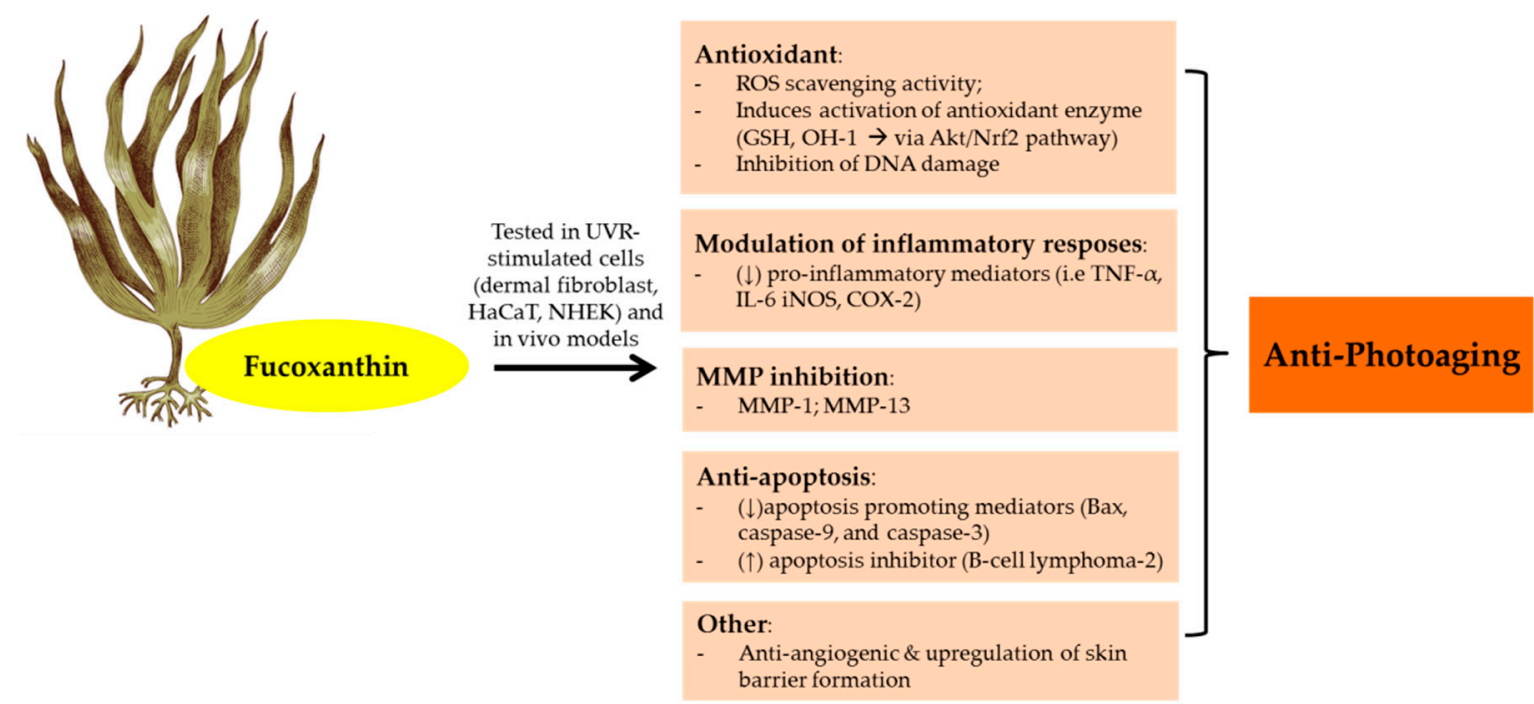

Figure 4. Anti-photoaging activity of fucoxanthin extracted from brown seaweeds. Abbreviations: Reactive oxygen speies (ROS); Human keratinocytes (HaCaT); Normal human epidermal keratinocytes (NHEK);Glutathione (GSH); Protein kinases B (Akt);Nuclear factor erythroid 2-related factor 2 (Nrf2); Matrix metalloproteinase (MMP); Tumor necrosis factor (TNF$\alpha)$; Interleukin (IL); Inducible nitric oxyde synthase (iNOS); Cyclooxygenase-2 (COX-2); Down-regulated, decreased ( $\downarrow$ ); Up-regulated, increased $(\uparrow)$.

Inflammatory stimuli could trigger MMP which leads to photoaging, and when UVB reaches our body, keratinocytes which represent the first target act as sentinels, initiate the signaling cascade. These events address the stress and the production of pro-inflammatory factors such as NO, PGE 2 , IL-6, IL- $1 \beta$ and TNF- $\alpha$. Furthermore, Luna et al., (2018) showed that pretreatment of $\mathrm{HaCaT}$ cells with fucoxanthin at $50 \mu \mathrm{M}$ reduced the downstream inflammatory cytokines (TNF- $\alpha$ and IL-6) [155]. In addition, the synergy effects of fucoxanthin and rosmarinic acid (phenolic ester isolated from Rosmarinus officinalis L) on UVB-exposed HaCaT have been demonstrated [156]. A combination of fucoxanthin $(5 \mu \mathrm{M})$ and rosmarinic acid $(5 \mu \mathrm{M})$ improved the antioxidant and anti-inflammatory profiles compared to individual compounds. The photo-protective effects of fucoxanthin and rosmarinic acid were mediated by down-regulation of NLR family pyrin domain containing 3 (NRLP3)-inflammasome and upregulation of Nrf2 signaling pathway which further increased the antioxidant gene expression (HO-1).

The levels of structural proteins for the epidermal permeability barrier, including filaggrin (filament aggregating protein) markedly decline in aged skin. UVR has been associated with the level of filaggrin, based on in vitro and in vivo experimental models [157]. Following UV exposure, filaggrin gene expression was down regulated. Furthermore, treatment with $0.5 \%$ fucoxanthin (4 days until day 8 ) stimulates filaggrin promoter activity and upregulates filaggrin gene expression [158]. This upregulation of the skin barrier formation by fucoxanthin may contribute to the photoprotective porperties of fucoxanthin. In addition, its treatment protects $\mathrm{HaCaT}$ cells from hydrogen peroxide-induced cell death. Fucoxanthin protective actions were mediated by the down-regulation of apoptosis promoting mediators (Bcl-2-associated $X$ protein (Bax), caspase-9, and caspase- 3 ) and the up-regulation of apoptosis inhibitor (B-cell lymphoma-2 Bcl-2) [152].

Continuous exposure to UV irradiation induces skin angiogenesis and wrinkle formation [159]. Furthermore, the topical administration of fucoxanthin $(0.001 \%)$ prior to 
UVB radiation in hairless mice showed potential anti-angiogenic effects. It also diminishes epidermal hypertrophy, MMP-13 expression in the epidermis and thiobarbituric acid reactive substances (TBARS) in the skin [151]. Other studies also showed that fucoxanthin treatment ameliorated UVB irradiation-induced corneal damage and down-regulating Vascular endothelial growth factor (VEGF) expression [160].

The possibility of administering fucoxanthin topically faces several drawbacks because of the issue of lipophilicity and HMW. Anti-photoaging agents need to diffuse across the stratum corneum and tight junctions to achieve effective permeation. Several vehicle such as hydrogel, cream, and ointment have been tested to achieve the best permeation results with cream showed the most favorable vehicle for fucoxanthin topical administration [155]. Furthermore, a cream containing fucoxanthin was applied in UVB-irradiated erythema model in hairless mice. It showed photoprotective properties through the down-regulation of COX-2 and iNOS and the up-regulation of HO-1 protein via Nrf-2 pathway. In addition, the effects of fucoxanthin $(0.5 \%$ in alkyl benzoate or in $\mathrm{EtOH})$ in reconstructed human skin have also been investigated and it was found that its topical applications were safe. Fucoxanthin treatment upon UVB irradiation in reconstructed human skin ameliorated proinflammatory mediators (IL-6 and IL-8) [161]. Collectively, it is believed that fucoxanthin could be a natural adjuvant for preventing photoaging.

\section{Potential of Seaweeds in Anti-photoaging Products}

\subsection{Seaweed Diversity Opens Untapped Potential for Anti-Photoaging Products}

Currently, more than 30,000 species of algae have been reported with about 15,000 species belonging to macroalgae (including terrestrial and seaweeds) [162]. These huge numbers of algal diversity offer great potential to be applied in the food, pharmacy, cosmetic and skincare industries. However, many seaweed species are still considered to be underexploited resources. An example is in Indonesia, where 1000 seaweed species have been reported. These marine organisms play an important ecologic and socioeconomic role in coastal communities and drive economic growth. However, only a few species have been commercialized (i.e., Kappaphycus alvarezii; previously known as Eucheuma cottonii, Eucheuma spinosum and Gracilaria sp) [15]. All commercialized seaweeds are commonly used in the hydrocolloid industry to produce agar and carrageenan. Hundreds of seaweed species are still categorized as under-explored, and these conditions also happen in many countries. The anti-photoaging properties of many seaweeds species remain unexplored and these renewable marine resources have an untapped potential to be developed in skincare and cosmetics industries.

\subsection{Development of Sustainable Aquaculture to Support Seaweeds Potential in Skincare and Cosmetic Industries}

Twenty three percent of the world's aquaculture production is from seaweeds, however, 'marine agronomy' is still in its infancy and seaweed potentials are still categorized as under-exploited (far from being fully exploited) [163]. With more seaweeds being used because of their anti-photoaging and other potential skin benefit effects, the demand for the use of seaweeds in cosmetic and skincare industries will grow globally. Therefore, the development of sustainable production of seaweed species through aquaculture is required [164]. To enhance seaweed production, it is important to understand and modify the main parameters that affect their cultivation. The parameters include water current and movement, water temperature, irradiance and photoperiod, nutrients dispersion and water quality, and the relationships of these factors and the intrinsic physiological responses [165].

The development of seaweed co-culture with other marine commodities can be easily carried out. Co-culture of seaweed with other marine flora or fauna could be carried out through a system called Integrated Multi-Trophic Aquaculture (IMTA). The IMTA system provide advantages environmentally, particularly in sustainability aquaculture, and social economic aspect [166]. Furthermore, it has also been useful in desired bioactive compound optimizations. 
Seaweed's reproduction and the synthesis of anti-photoaging compounds may occur after some stress stimulus. For example, IMTA of Rhodymenia pseudopalmata with commercial marine fish (common snook; Centropomus undecimalis) under exposure to high solar radiation has also been investigated. While that of R. pseudopalmata increased anti-photoaging compounds such as MAAs (Porphyra-334, shinorine, palythine, palythinol, palythene usujirene, and asterina-330), radical scavenging activities, phenol, and natural pigment contents [167]. The culture of Gracilaria vermiculophylla in outdoor tanks in seawater with the addition of fishpond effluents in an IMTA system has also been demonstrated [168]. The highest MAAs content was observed in April and four MAAs were identified (Porphyra-334, Shinorine, Palythine and Asterina-330). Furthermore, the IMTA development of seaweed with other marine commodities could be used to optimize anti-photoaging compounds and provide another economic benefit for seaweed farmers.

\subsection{Sustainable and Environmentally Friendly Extraction}

Multiple solvent extractions have been used with other common methods to obtain anti-photoaging compounds from seaweeds. The extraction process involves a combination of various solvent such as methanol, n-hexane, dichloromethane, chloroform, and acetone. However, most of the solvent used in the extraction process are of safety concerns due to the hazardous, toxicity and impact to the environment. Many research groups have developed sustainable extraction technologies to obtain anti-photoaging compounds from seaweeds. These includes microwave assisted extraction (MAE), ultrasound assisted extraction (UAE), supercritical fluid extraction (SFE) and pressurized liquid extraction (PLE) [169]. These green technologies were able to extract anti-photoaging compounds from seaweed effectively.

Many studies have extracted one of the anti-photoaging compounds (fucoxanthin) from $U$. pinnatifida with various methods from solvent extraction to SFE, MAE and UAE (Table 6). U. pinnatifida, is one of the most studied brown seaweed species by many research groups in Japan, Korea, and China. Based on the extraction yield of fucoxanthin, SFE may be considered as the best non-conventional extraction technique. One of the advantages of this system is the use of $\mathrm{CO}_{2}$ as a solvent, an easy-available compound which is nontoxic [170]. The SFE systems could be an efficient and respectful option for the production of fucoxanthin for cosmetic and skincare industries. However, these extraction processes have some weakness which includes cost of the installations and special manpower to operate it. In addition to extraction processes, sample pre-treatment could be another factor used in optimizing the extraction yield of anti-photoaging compounds from seaweeds.

Through the use of an environmentally friendly technology PLE, Saravana et al. (2018) optimized the extraction of fucoidan from Saccharina japonica. These processes involve solvent pressurized at certain temperature and pressure under critical level conditions (subcritical region). Under this condition, seaweed-solvent matrix is treated to a pressurized temperature from 100 to $374{ }^{\circ} \mathrm{C}$ with a pressure that is up to $22 \mathrm{MPa}$, and the solvent is maintained in the liquid state by operating with a constant pressure higher than that of the vapor. Furthermore, the subcritical condition facilitates an increase in dielectric constant and decrease in density which cause hydrocarbons to become more soluble, allowing complex reactions like decomposition and depolymerization to occur [171]. It was found that the most optimal conditions in PLE process for fucoidan extraction were extraction at $127.01{ }^{\circ} \mathrm{C}, 80 \mathrm{bar}, \mathrm{S} / \mathrm{L}$ ratio of $0.04 \mathrm{~g} / \mathrm{mL}$, agitation speed of $300 \mathrm{rpm}$ for $11.98 \mathrm{~min}$ [172]. The PLE process produced a high yield of fucoidan $(13.56 \%)$ with good functional activity. Therefore, PLE might be the favored method for the extraction of fucoidan in the skincare and cosmetic industries. 
Table 6. Fucoxanthin extraction from Undaria pinnatifida using different extraction techniques.

\begin{tabular}{|c|c|c|c|c|c|c|}
\hline $\begin{array}{l}\text { Extraction } \\
\text { Method }\end{array}$ & $\begin{array}{l}\text { Solvent } \\
\text { Extraction }\end{array}$ & $\begin{array}{l}\text { Solvent } \\
\text { Extraction }\end{array}$ & SFE & SFE & UAE & MAE \\
\hline Solvent & $\mathrm{MeOH}(1: 50 w / v)$ & $\mathrm{MeOH}(1: 50 w / v)$ & $\begin{array}{l}\mathrm{CO}_{2} \text { and } \mathrm{EtOH} \\
(3 \%, v / v)\end{array}$ & $\mathrm{CO}_{2}$ & $\begin{array}{l}\text { Deionized } \mathrm{H}_{2} \mathrm{O} \\
(1: 100 w / v)\end{array}$ & $\begin{array}{l}\text { EtOH }(15: 1 \\
w / v)\end{array}$ \\
\hline Pretreatment & $\begin{array}{l}\text { Wash, salted, } \\
\text { boiled, } \\
\text { blanched, cured }\end{array}$ & Avoid sunlight & Freeze dry & $\begin{array}{l}\text { Milling and } \\
\text { microwave } \\
\text { assisted cell } \\
\text { disruption }\end{array}$ & NA & NA \\
\hline $\begin{array}{l}\text { Extraction } \\
\text { condition }\end{array}$ & $1 \mathrm{~h}, \mathrm{RT}$ & $1 \mathrm{~h}, \mathrm{RT}$ & $\begin{array}{l}50 \text { bar, } 200^{\circ} \mathrm{C}, \\
1 \mathrm{~h}\end{array}$ & $\begin{array}{l}40 \text { bar, } 400{ }^{\circ} \mathrm{C}, \\
3 \mathrm{~h}\end{array}$ & $\begin{array}{l}800 \mathrm{~W}, 80 \% \\
\text { amplitude, } 20 \\
\mathrm{kHz}, 30^{\circ} \mathrm{C}, 3 \mathrm{~h} .\end{array}$ & $\begin{array}{l}\text { ratios, } 60^{\circ} \mathrm{C} \text {, } \\
10 \mathrm{~min}, 300 \mathrm{~W}\end{array}$ \\
\hline Yield & $2.08 \pm 0.04 \mathrm{mg} / \mathrm{g}$ & $4.96 \pm 0.4 \mathrm{mg} / \mathrm{g}$ & $0.00753 \mu \mathrm{g} / \mathrm{g}$ & $38.5 \mathrm{mg} / \mathrm{g}$ & $0.031 \mathrm{mg} / \mathrm{g}$ & $2.12 \mathrm{mg} / 100 \mathrm{~g}$ \\
\hline Notes & Processed & Fresh & $\begin{array}{l}\text { Pressure and } \\
\text { temperature } \\
\text { affect yield }\end{array}$ & $\begin{array}{l}\text { MW } \\
\text { pretreatment } \\
\text { increased fucox- } \\
\text { anthin yield }\end{array}$ & $\begin{array}{l}\text { Sporophyll; } \\
\text { small pilot scale }\end{array}$ & $\begin{array}{l}\text { No effect on } \\
\text { microwave } \\
\text { power }\end{array}$ \\
\hline Ref & [173] & [173] & [174] & [175] & [176] & [177] \\
\hline
\end{tabular}

Abbreviations: Microwave assisted extraction (MAE); Ultrasound assisted extraction (UAE); Supercritical fluid extraction (SFE); Methanol (MeOH); Ethanol (EtOH); Carbon dioxide $\left(\mathrm{CO}_{2} ;\right.$, Molecular weight (MW); Weight/volume ( $\left.w / v\right)$, Volume/volume (v/v); Room Temperature (RT).

Collectively, many anti-photoaging substances could be extracted using environmentally friendly technologies. Selecting an extraction process is a key factor in achieving optimum extraction yields, desired biological activity and reduce production costs. In addition, the use of environmentally friendly extraction may increase the commercial value of the final cosmetic or skincare product. This is because there is usually a high demand for more natural, non-toxic, and ecofriendly products.

\subsection{Potential of Seaweeds-Derived Anti-Photoaging Products in the Market}

The skincare and cosmetic industries have become two of the fastest growing and prosperous industry sectors [178]. The demand for new and innovative anti-photoaging products are continuously growing. Seaweeds anti-photoaging products have been developed and are commercially available in the market. Undaria pinnatifida extracts (containing $85 \%$ fucoidan) and Fucus vesiculosus extracts (containing $60 \%$ fucoidan and 30\% polyphenol) have been tested in clinical studies. Both seaweed extracts increased the expression of sirtuin 1 (SIRT1), a protein known for its longevity-boosting and anti-ageing activity. Furthermore, clinical testing established the efficacy of the extracts in a range of tested applications, relative to placebo. The anti-photoaging properties of $U$. pinnatifida extract is modulation of skin immunity, soothing and protection, while Fucus vesiculosus extract significantly affected age spot reduction and increased brightness, soothing, and protection [50]. These brown seaweed extracts are currently available in the market under Marinova's (Biotech Company from Autralia). In addition, other anti-photoaging extracts containing MAAs are also available on the market (Table 7). Seaweed derived anti-photoaging compounds need to be explored and are highly recommended as an active ingredient in sunscreen, anti-photoaging cream, moisturizers in skincare and cosmetics. In addition, environmentally friendly technology need be developed so the eco-friendly cosmetic and skincare could be more available in the market. 
Table 7. Anti-aging and photoproctive ingredients from seaweeds available in the market.

\begin{tabular}{lllll}
\hline Algae Species & Trade Name & Company & $\begin{array}{l}\text { Active } \\
\text { Ingredients }\end{array}$ & Anti-Photoaging \\
\hline $\begin{array}{l}\text { Poprphyra } \\
\text { umbilicalis }\end{array}$ & Helionori $^{\circledR}$ & Gelyma, French & MAAs & $\begin{array}{l}\text { Photoprotective (UV-A) } \\
\text { DNA protection } \\
\text { Prevention of sunburn }\end{array}$ \\
$\begin{array}{l}\text { Poprphyra } \\
\text { umbilicalis }\end{array}$ & Helioguard365 & $\begin{array}{l}\text { Mibelle } \\
\text { Biochemistry, } \\
\text { Switzerland }\end{array}$ & $\begin{array}{l}\text { Porphyra-334 and } \\
\text { Shinorine }\end{array}$ & Photoprotective (UV-A) \\
\hline $\begin{array}{l}\text { Poprphyra } \\
\text { umbilicalis }\end{array}$ & $\begin{array}{l}\text { Algae gorria; Alga } \\
\text { marris }\end{array}$ & $\begin{array}{l}\text { Laboratoires de } \\
\text { biarritz, French }\end{array}$ & NA & [180] \\
\hline $\begin{array}{l}\text { Undaria pinnatifida } \\
\text { Fucus vesiculosus }\end{array}$ & Fucorich & $\begin{array}{l}\text { Marinova, } \\
\text { Australia }\end{array}$ & Fucoidan & Photoprotective (UV-A) \\
\hline [181] \\
\hline $\begin{array}{l}\text { Fucus vesiculosus } \\
\text { Maritech reverse }\end{array}$ & $\begin{array}{l}\text { Marinova, } \\
\text { Australia }\end{array}$ & $\begin{array}{l}\text { Fucoidan } \\
\text { [182] }\end{array}$ \\
\hline
\end{tabular}

Abbreviations: Mycosporine like amino acids (MAAs); Ultraviolet (UV).

\section{Conclusions}

There are still large opportunities to explore seaweed-derived bioactive compounds as anti-photoaging agents in the skincare and cosmetic industries. Furthermore, more studies need to be carried out on the sustainable culture of seaweeds and their optimization in order to obtain optimal bioactive compounds. There are still challenges involving the use of environmentally friendly technology for industrial applications. Therefore, the development of seaweeds in skincare and cosmetic industries is important but poses a challenge for scientists, engineers, seaweed farmers, skincare and cosmetic formulators, and product developers.

Author Contributions: Conceptualization, R.P.; writing-original draft preparation, R.P.; review and editing, R.P., S.-K.K., K.-H.S.; supervision, S.-K.K. All authors have read and agreed to the published version of the manuscript.

Funding: This study is supported by National Research Priority (PRN)-Development of Marine Micro and Macro-algae from Indonesia (MALSAI) WBS-1 (Contract no: 191/E1/PRN/2020) from the Indonesian Institute of Sciences (LIPI), National Research and Innovation Agency (BRIN) and Indonesia Endowment Fund for Education (LPDP), Rep. of Indonesia 2021.

Informed Consent Statement: Not applicable.

Conflicts of Interest: The authors declare no conflict of interest.

\section{References}

1. Abdallah, F.; Mijouin, L.; Pichon, C. Skin immune landscape: Inside and outside the organism. Mediat. Inflamm. 2017, 2017, 1-17. [CrossRef] [PubMed]

2. Solano, F. Photoprotection and skin pigmentation: Melanin-related molecules and some other new agents obtained from natural sources. Molecules 2020, 25, 1537. [CrossRef] [PubMed]

3. Agar, N.; Young, A.R. Melanogenesis: A photoprotective response to DNA damage? Mutat. Res. Fundam. Mol. Mech. Mutagenesis 2005, 571, 121-132. [CrossRef]

4. Solano, F. Photoprotection versus photodamage: Updating an old but still unsolved controversy about melanin. Polym. Int. 2016, 65, 1276-1287. [CrossRef]

5. Xu, Y.; Fisher, G.J. Ultraviolet (UV) light irradiation induced signal transduction in skin photoaging. J. Dermatol. Sci. Suppl. 2005, 1, S1-S8. [CrossRef]

6. Ichihashi, M.; Ando, H.; Yoshida, M.; Niki, Y.; Matsui, M. Photoaging of the skin. Anti Aging Med. 2009, 6, 46-59. [CrossRef] 
7. Panich, U.; Sittithumcharee, G.; Rathviboon, N.; Jirawatnotai, S. Ultraviolet Radiation-Induced Skin Aging: The Role of DNA Damage and Oxidative Stress in Epidermal Stem Cell Damage Mediated Skin Aging. Stem Cells Int. 2016, $2016,7370642$. [CrossRef] [PubMed]

8. Pandel, R.; Poljšak, B.; Godic, A.; Dahmane, R. Skin photoaging and the role of antioxidants in its prevention. Int. Sch. Res. Not. 2013, 2013. [CrossRef]

9. Wlaschek, M.; Tantcheva-Poór, I.; Naderi, L.; Ma, W.; Schneider, L.A.; Razi-Wolf, Z.; Schüller, J.; Scharffetter-Kochanek, K. Solar UV irradiation and dermal photoaging. J. Photochem. Photobiol. B: Biol. 2001, 63, 41-51. [CrossRef]

10. Dahmane, R.; Pandel, R.; Trebse, P.; Poljsak, B. The Role of Sun Exposure in Skin Aging. In Sun Exposure: Risk Factors, Protection Practices and Health Effects; Nova Science Publishers, Inc.: Hauppauge, NY, USA, 2015; Volume 2015, pp. 1-40.

11. Wang, M.; Charareh, P.; Lei, X.; Zhong, J.L. Autophagy: Multiple Mechanisms to Protect Skin from Ultraviolet Radiation-Driven Photoaging. Oxidative Med. Cell. Longev. 2019, 2019, 8135985. [CrossRef]

12. Parvez, S.; Kang, M.; Chung, H.S.; Cho, C.; Hong, M.C.; Shin, M.K.; Bae, H. Survey and mechanism of skin depigmenting and lightening agents. Phytother. Res. Int. J. Devoted Pharmacol. Toxicol. Eval. Nat. Prod. Deriv. 2006, 20, 921-934. [CrossRef] [PubMed]

13. Pangestuti, R.; Siahaan, E.; Kim, S.-K. Photoprotective Substances Derived from Marine Algae. Mar. Drugs 2018, 16, 399. [CrossRef] [PubMed]

14. Kim, S.-K.; Pangestuti, R. 15 Biological Properties of Cosmeceuticals Derived from Marine Algae. In Marine Cosmeceuticals: Trends Prospect; Kim, S.K., Ed.; CRC Press: Boca Raton, FL, USA, 2011; pp. 191-200.

15. Pangestuti, R.; Getachew, A.T.; Siahaan, E.A.; Chun, B.-S. Characterization of functional materials derived from tropical red seaweed Hypnea musciformis produced by subcritical water extraction systems. J. Appl. Phycol. 2019, 31, 2517-2528. [CrossRef]

16. Wijesekara, I.; Pangestuti, R.; Kim, S.K. Biological activities and potential health benefits of sulfated polysaccharides derived from marine algae. Carbohydr. Polym. 2010, 84, 14-21. [CrossRef]

17. Pangestuti, R.; Kim, S.-K. Biological activities of carrageenan. Mar. Carbohydr. Fundam. Appl. 2014, 72, 113-124.

18. Zargarzadeh, M.; Amaral, A.J.R.; Custódio, C.A.; Mano, J.F. Biomedical applications of laminarin. Carbohydr. Polym. 2020, 232, 115774. [CrossRef]

19. Ku, M.-J.; Jung, J.-W.; Lee, M.-S.; Cho, B.-K.; Lee, S.-R.; Lee, H.-S.; Vischuk, O.S.; Zvyagintseva, T.N.; Ermakova, S.P.; Lee, Y.-H. Effect of Fucus evanescens fucoidan on expression of matrix metalloproteinase-1 promoter, mRNA, protein and signal pathway. J. Life Sci. 2010, 20, 1603-1610. [CrossRef]

20. Freitas, R.; Martins, A.; Silva, J.; Alves, C.; Pinteus, S.; Alves, J.; Teodoro, F.; Ribeiro, H.M.; Gonçalves, L.; Petrovski, Ž. Highlighting the Biological Potential of the Brown Seaweed Fucus spiralis for Skin Applications. Antioxidants 2020, 9, 611. [CrossRef] [PubMed]

21. Jesumani, V.; Du, H.; Pei, P.; Aslam, M.; Huang, N. Comparative study on skin protection activity of polyphenol-rich extract and polysaccharide-rich extract from Sargassum vachellianum. PLoS ONE 2020, 15, e0227308. [CrossRef]

22. Pangestuti, R.; Kim, S.-K. Biological activities and health benefit effects of natural pigments derived from marine algae. J. Funct. Foods 2011, 3, 255-266. [CrossRef]

23. Sánchez-Lamar, Á.; González-Pumariega, M.; Fuentes-León, F.; Vernhes Tamayo, M.; Schuch, A.P.; Menck, C.F. Evaluation of Genotoxic and DNA Photo-Protective Activity of Bryothamnion triquetrum and Halimeda incrassata Seaweeds Extracts. Cosmetics 2017, 4, 23. [CrossRef]

24. Wiraguna, A.A.G.P.; Pangkahila, W.; Astawa, I.N.M. Antioxidant properties of topical Caulerpa sp. extract on UVB-induced photoaging in mice. Dermatol. Rep. 2018, 10, 20-25. [CrossRef] [PubMed]

25. Guinea, M.; Franco, V.; Araujo-Bazán, L.; Rodríguez-Martín, I.; González, S. In vivo UVB-photoprotective activity of extracts from commercial marine macroalgae. Food Chem. Toxicol. 2012, 50, 1109-1117. [CrossRef]

26. Kim, S.; You, D.H.; Han, T.; Choi, E.-M. Modulation of viability and apoptosis of UVB-exposed human keratinocyte HaCaT cells by aqueous methanol extract of laver (Porphyra yezoensis). J. Photochem. Photobiol. B Biol. 2014, 141, 301-307. [CrossRef]

27. Rangel, K.C.; Villela, L.Z.; de Castro Pereira, K.; Colepicolo, P.; Debonsi, H.M.; Gaspar, L.R. Assessment of the photoprotective potential and toxicity of Antarctic red macroalgae extracts from Curdiea racovitzae and Iridaea cordata for cosmetic use. Algal Res. 2020, 50, 101984. [CrossRef]

28. Mercurio, D.; Wagemaker, T.; Alves, V.; Benevenuto, C.; Gaspar, L.; Campos, P.M. In vivo photoprotective effects of cosmetic formulations containing UV filters, vitamins, Ginkgo biloba and red algae extracts. J. Photochem. Photobiol. B Biol. 2015, 153, 121-126. [CrossRef] [PubMed]

29. Boulho, R.; Le Roux, J.; Le Quémener, C.; Audo, G.; Bourgougnon, N.; Bedoux, G. Fractionation of UV-B absorbing molecules and of free radical scavenging compounds from Solieria chordalis by using centrifugal partition chromatography. Phytochem. Lett. 2017, 20, 410-414. [CrossRef]

30. Kim, H.M.; Lee, D.E.; Park, S.D.; Kim, Y.T.; Kim, Y.J.; Jeong, J.W.; Lee, J.-H.; Jang, S.S.; Chung, D.K.; Sim, J.-H. Preventive effect of fermented Gelidium amansii and Cirsium japonicum extract mixture against UVB-induced skin photoaging in hairless mice. Food Sci. Biotechnol. 2014, 23, 623-631. [CrossRef]

31. Hyun, Y.J.; Piao, M.J.; Kim, K.C.; Zheng, J.; Yao, C.W.; Cha, J.W.; Kang, H.K.; Yoo, E.S.; Koh, Y.S.; Lee, N.H. Photoprotective effect of a Polyopes affinis (Harvey) Kawaguchi and Wang (Halymeniaceae)-derived ethanol extract on human keratinocytes. Trop. J. Pharm. Res. 2014, 13, 863-871. [CrossRef]

32. Bedoux, G.; Hardouin, K.; Marty, C.; Taupin, L.; Vandanjon, L.; Bourgougnon, N. Chemical characterization and photoprotective activity measurement of extracts from the red macroalga Solieria chordalis. Bot. Mar. 2014, 57, 291-301. [CrossRef] 
33. Piao, M.J.; Kang, H.K.; Yoo, E.S.; Koh, Y.S.; Kim, D.S.; Lee, N.H.; Hyun, J.W. Photo-protective effect of Polysiphonia morrowii Harvey against ultraviolet B radiation-induced keratinocyte damage. J. Korean Soc. Appl. Biol. Chem. 2012, 55, 149-158. [CrossRef]

34. Piao, M.J.; Hyun, Y.J.; Oh, T.-H.; Kang, H.K.; Yoo, E.S.; Koh, Y.S.; Lee, N.H.; Suh, I.S.; Hyun, J.W. Chondracanthus tenellus (Harvey) hommersand extract protects the human keratinocyte cell line by blocking free radicals and UVB radiation-induced cell damage. In Vitro Cell. Dev. Biol. Anim. 2012, 48, 666-674. [CrossRef]

35. Piao, M.J.; Hyun, Y.J.; Cho, S.J.; Kang, H.K.; Yoo, E.S.; Koh, Y.S.; Lee, N.H.; Ko, M.H.; Hyun, J.W. An ethanol extract derived from Bonnemaisonia hamifera scavenges ultraviolet $\mathrm{B}(\mathrm{UVB})$ radiation-induced reactive oxygen species and attenuates UVB-induced cell damage in human keratinocytes. Mar. Drugs 2012, 10, 2826-2845. [CrossRef] [PubMed]

36. Kim, A.D.; Piao, M.J.; Hyun, Y.J.; Kang, H.K.; Suh, I.S.; Lee, N.H.; Hyun, J.W. Photo-protective properties of Lomentaria hakodatensis yendo against ultraviolet B radiation-induced keratinocyte damage. Biotechnol. Bioprocess Eng. 2012, 17, $1223-1231$. [CrossRef]

37. Piao, M.J.; Yoon, W.J.; Kang, H.K.; Yoo, E.S.; Koh, Y.S.; Kim, D.S.; Lee, N.H.; Hyun, J.W. Protective Effect of the Ethyl Acetate Fraction of Sargassum muticum Against Ultraviolet B-Irradiated Damage in Human Keratinocytes. Int. J. Mol. Sci. 2011, 12, 8146-8160. [CrossRef]

38. Piao, M.J.; Kim, K.C.; Zheng, J.; Yao, C.W.; Cha, J.W.; Boo, S.J.; Yoon, W.J.; Kang, H.K.; Yoo, E.S.; Koh, Y.S. The ethyl acetate fraction of Sargassum muticum attenuates ultraviolet B radiation-induced apoptotic cell death via regulation of MAPK-and caspase-dependent signaling pathways in human HaCaT keratinocytes. Pharm. Biol. 2014, 52, 1110-1118. [CrossRef] [PubMed]

39. Song, J.H.; Piao, M.J.; Han, X.; Kang, K.A.; Kang, H.K.; Yoon, W.J.; Ko, M.H.; Lee, N.H.; Lee, M.Y.; Chae, S. Anti-wrinkle effects of Sargassum muticum ethyl acetate fraction on ultraviolet B-irradiated hairless mouse skin and mechanistic evaluation in the human HaCaT keratinocyte cell line. Mol. Med. Rep. 2016, 14, 2937-2944. [CrossRef]

40. Li, Z.-y.; Yu, C.-H.; Lin, Y.-T.; Su, H.-L.; Kan, K.-W.; Liu, F.-C.; Chen, C.-T.; Lin, Y.-T.; Hsu, H.-F.; Lin, Y.-H. The potential application of spring Sargassum glaucescens extracts in the moisture-retention of keratinocytes and dermal fibroblast regeneration after UVA-irradiation. Cosmetics 2019, 6, 17. [CrossRef]

41. Prasedya, E.S.; Syafitri, S.M.; Geraldine, B.A.; Hamdin, C.D.; Frediansyah, A.; Miyake, M.; Kobayashi, D.; Hazama, A.; Sunarpi, H. UVA photoprotective activity of Brown macroalgae Sargassum cristafolium. Biomedicines 2019, 7, 77. [CrossRef] [PubMed]

42. Hyun, Y.J.; Piao, M.J.; Ko, M.H.; Lee, N.H.; Kang, H.K.; Yoo, E.S.; Koh, Y.S.; Hyun, J.W. Photoprotective effect of Undaria crenata against ultraviolet B-induced damage to keratinocytes. J. Biosci. Bioeng. 2013, 116, 256-264. [CrossRef]

43. Zheng, J.; Hewage, S.M.; Piao, M.J.; Kang, K.A.; Han, X.; Kang, H.; Yoo, E.; Koh, Y.; Lee, N.; Ko, C. Photoprotective effect of carpomitra costata extract against ultraviolet B-induced oxidative damage in human keratinocytes. J. Environ. Pathol. Toxicol. Oncol. 2016, 35, 11-28. [CrossRef] [PubMed]

44. Jun, E.-S.; Kim, Y.J.; Kim, H.-H.; Park, S.Y. Gold Nanoparticles Using Ecklonia stolonifera Protect Human Dermal Fibroblasts from UVA-Induced Senescence through Inhibiting MMP-1 and MMP-3. Mar. Drugs 2020, 18, 433. [CrossRef] [PubMed]

45. Ale, M.T.; Maruyama, H.; Tamauchi, H.; Mikkelsen, J.D.; Meyer, A.S. Fucose-containing sulfated polysaccharides from brown seaweeds inhibit proliferation of melanoma cells and induce apoptosis by activation of caspase-3 in vitro. Mar. Drugs 2011, 9 , 2605-2621. [CrossRef]

46. Wang, L.; Lee, W.; Oh, J.Y.; Cui, Y.R.; Ryu, B.; Jeon, Y.-J. Protective effect of sulfated polysaccharides from celluclast-assisted extract of Hizikia fusiforme against ultraviolet B-Induced skin damage by regulating NF- $\mathrm{kB}, \mathrm{AP}-1$, and MAPKs signaling pathways in vitro in human dermal fibroblasts. Mar. Drugs 2018, 16, 239. [CrossRef]

47. Wang, L.; Oh, J.Y.; Yang, H.-W.; Kim, H.S.; Jeon, Y.-J. Protective effect of sulfated polysaccharides from a Celluclast-assisted extract of Hizikia fusiforme against ultraviolet B-induced photoaging in vitro in human keratinocytes and in vivo in zebrafish. Mar. Life Sci. Technol. 2019, 1, 104-111. [CrossRef]

48. Ye, Y.; Ji, D.; You, L.; Zhou, L.; Zhao, Z.; Brennan, C. Structural properties and protective effect of Sargassum fusiforme polysaccharides against ultraviolet B radiation in hairless Kun Ming mice. J. Funct. Foods 2018, 43, 8-16. [CrossRef]

49. Wang, L.; Jayawardena, T.U.; Yang, H.-W.; Lee, H.-G.; Jeon, Y.-J. The Potential of Sulfated Polysaccharides Isolated from the Brown Seaweed Ecklonia maxima in Cosmetics: Antioxidant, Anti-melanogenesis, and Photoprotective Activities. Antioxidants 2020, 9, 724. [CrossRef]

50. Fitton, J.H.; Dell'Acqua, G.; Gardiner, V.-A.; Karpiniec, S.S.; Stringer, D.N.; Davis, E. Topical benefits of two fucoidan-rich extracts from marine macroalgae. Cosmetics 2015, 2, 66-81. [CrossRef]

51. Gesztesi, J.-1.; Silva, L.V.N.; Robert, L.; Robert, A. Cosmetic composition of two polysaccharides based on fucose and rhamnose. Google Patents Patent number: S20060115443A1, 1 June 2006.

52. Wang, J.; Zhang, Q.; Zhang, Z.; Song, H.; Li, P. Potential antioxidant and anticoagulant capacity of low molecular weight fucoidan fractions extracted from Laminaria japonica. Int. J. Biol. Macromol. 2010, 46, 6-12. [CrossRef]

53. Wang, J.; Zhang, Q.; Zhang, Z.; Zhang, J.; Li, P. Synthesized phosphorylated and aminated derivatives of fucoidan and their potential antioxidant activity in vitro. Int. J. Biol. Macromol. 2009, 44, 170-174. [CrossRef]

54. Wang, J.; Liu, L.; Zhang, Q.; Zhang, Z.; Qi, H.; Li, P. Synthesized oversulphated, acetylated and benzoylated derivatives of fucoidan extracted from Laminaria japonica and their potential antioxidant activity in vitro. Food Chem. 2009, 114, 1285-1290. [CrossRef]

55. Koh, H.S.A.; Lu, J.; Zhou, W. Structure characterization and antioxidant activity of fucoidan isolated from Undaria pinnatifida grown in New Zealand. Carbohydr. Polym. 2019, 212, 178-185. [CrossRef] [PubMed] 
56. Khalafu, S.H.S.; Aida, W.M.W.; Lim, S.J.; Maskat, M.Y. Effects of deodorisation methods on volatile compounds, chemical properties and antioxidant activities of fucoidan isolated from brown seaweed (Sargassum sp.). Algal Res. 2017, 25, 507-515. [CrossRef]

57. Lim, S.J.; Aida, W.M.W.; Maskat, M.Y.; Mamot, S.; Ropien, J.; Mohd, D.M. Isolation and antioxidant capacity of fucoidan from selected Malaysian seaweeds. Food Hydrocoll. 2014, 42, 280-288. [CrossRef]

58. Moon, H.J.; Lee, S.R.; Shim, S.N.; Jeong, S.H.; Stonik, V.A.; Rasskazov, V.A.; Zvyagintseva, T.; Lee, Y.H. Fucoidan inhibits UVB-induced MMP-1 expression in human skin fibroblasts. Biol. Pharm. Bull. 2008, 31, 284-289. [CrossRef]

59. Moon, H.J.; Park, K.S.; Ku, M.J.; Lee, M.S.; Jeong, S.H.; Imbs, T.I.; Zvyagintseva, T.N.; Ermakova, S.P.; Lee, Y.H. Effect of Costaria costata fucoidan on expression of matrix metalloproteinase-1 promoter, mRNA, and protein. J. Nat. Prod. 2009, 72, 1731-1734. [CrossRef]

60. Moon, H.J.; Lee, S.H.; Ku, M.J.; Yu, B.C.; Jeon, M.J.; Jeong, S.H.; Stonik, V.A.; Zvyagintseva, T.N.; Ermakova, S.P.; Lee, Y.H. Fucoidan inhibits UVB-induced MMP-1 promoter expression and down regulation of type I procollagen synthesis in human skin fibroblasts. Eur. J. Dermatol. 2009, 19, 129-134. [CrossRef]

61. Ku, M.-J.; Lee, M.-S.; Moon, H.-J.; Lee, Y.-H. Protective Effects of Fucoidan against UVB-Induced Oxidative Stress in Human Skin Fibroblasts. J. Life Sci. 2010, 20, 27-32. [CrossRef]

62. Hwang, P.-A.; Yan, M.-D.; Kuo, K.-L.; Phan, N.N.; Lin, Y.-C. A mechanism of low molecular weight fucoidans degraded by enzymatic and acidic hydrolysis for the prevention of UVB damage. J. Appl. Phycol. 2017, 29, 521-529. [CrossRef]

63. Kim, Y.-I.; Oh, W.-S.; Song, P.H.; Yun, S.; Kwon, Y.-S.; Lee, Y.J.; Ku, S.-K.; Song, C.-H.; Oh, T.-H. Anti-photoaging effects of low molecular-weight fucoidan on ultraviolet B-irradiated mice. Mar. Drugs 2018, 16, 286. [CrossRef]

64. Fernando, I.P.S.; Dias, M.K.H.M.; Madusanka, D.M.D.; Han, E.J.; Kim, M.J.; Jeon, Y.-J.; Lee, K.; Cheong, S.H.; Han, Y.S.; Park, S.R. Human Keratinocyte UVB-Protective Effects of a Low Molecular Weight Fucoidan from Sargassum horneri Purified by Step Gradient Ethanol Precipitation. Antioxidants 2020, 9, 340. [CrossRef]

65. Fernando, I.P.S.; Dias, M.K.H.M.; Madusanka, D.M.D.; Han, E.J.; Kim, M.J.; Jeon, Y.-J.; Ahn, G. Step gradient alcohol precipitation for the purification of low molecular weight fucoidan from Sargassum siliquastrum and its UVB protective effects. Int. J. Biol. Macromol. 2020, 163, 26-35. [CrossRef] [PubMed]

66. Su, W.; Wang, L.; Fu, X.; Ni, L.; Duan, D.; Xu, J.; Gao, X. Protective effect of a fucose-rich fucoidan isolated from Saccharina japonica against ultraviolet B-induced photodamage in vitro in human keratinocytes and in vivo in zebrafish. Mar. Drugs 2020, 18, 316. [CrossRef]

67. Wang, L.; Oh, J.-Y.; Kim, Y.-S.; Lee, H.-G.; Lee, J.-S.; Jeon, Y.-J. Anti-Photoaging and Anti-Melanogenesis Effects of Fucoidan Isolated from Hizikia fusiforme and Its Underlying Mechanisms. Mar. Drugs 2020, 18, 427. [CrossRef]

68. Wang, L.; Oh, J.-Y.; Lee, W.; Jeon, Y.-J. Fucoidan isolated from Hizikia fusiforme suppresses ultraviolet B-induced photodamage by down-regulating the expressions of matrix metalloproteinases and pro-inflammatory cytokines via inhibiting NF- $\mathrm{B}$, AP-1, and MAPK signaling pathways. Int. J. Biol. Macromol. 2021, 166, 751-759. [CrossRef] [PubMed]

69. Zayed, A.; El-Aasr, M.; Ibrahim, A.-R.S.; Ulber, R. Fucoidan Characterization: Determination of Purity and Physicochemical and Chemical Properties. Mar. Drugs 2020, 18, 571. [CrossRef] [PubMed]

70. Mak, W.; Hamid, N.; Liu, T.; Lu, J.; White, W. Fucoidan from New Zealand Undaria pinnatifida: Monthly variations and determination of antioxidant activities. Carbohydr. Polym. 2013, 95, 606-614. [CrossRef]

71. Ponce, N.M.A.; Stortz, C.A. A Comprehensive and Comparative Analysis of the Fucoidan Compositional Data across the Phaeophyceae. Front. Plant Sci. 2020, 11, 1844. [CrossRef] [PubMed]

72. Morya, V.; Kim, J.; Kim, E.-K. Algal fucoidan: Structural and size-dependent bioactivities and their perspectives. Appl. Microbiol. Biotechnol. 2012, 93, 71-82. [CrossRef]

73. García-Vaquero, M.; Rajauria, G.; O'doherty, J.; Sweeney, T. Polysaccharides from macroalgae: Recent advances, innovative technologies and challenges in extraction and purification. Food Res. Int. 2017, 99, 1011-1020. [CrossRef]

74. Ale, M.T.; Mikkelsen, J.D.; Meyer, A.S. Important determinants for fucoidan bioactivity: A critical review of structure-function relations and extraction methods for fucose-containing sulfated polysaccharides from brown seaweeds. Mar. Drugs 2011, 9, 2106-2130. [CrossRef]

75. Pozharitskaya, O.N.; Shikov, A.N.; Obluchinskaya, E.D.; Vuorela, H. The pharmacokinetics of fucoidan after topical application to rats. Mar. Drugs 2019, 17, 687. [CrossRef]

76. Kumar, A.; Singh, P.; Gupta, V.; Prakash, B. Application of nanotechnology to boost the functional and preservative properties of essential oils. In Functional and Preservative Properties of Phytochemicals; Elsevier: Amsterdam, The Netherlands, 2020; pp. 241-267.

77. Pereira, L. Seaweeds as source of bioactive substances and skin care therapy-Cosmeceuticals, algotheraphy, and thalassotherapy. Cosmetics 2018, 5, 68. [CrossRef]

78. de Souza, M.C.R.; Marques, C.T.; Dore, C.M.G.; da Silva, F.R.F.; Rocha, H.A.O.; Leite, E.L. Antioxidant activities of sulfated polysaccharides from brown and red seaweeds. J. Appl. Phycol. 2007, 19, 153-160. [CrossRef] [PubMed]

79. Sokolova, E.; Barabanova, A.; Homenko, V.; Solov'eva, T.; Bogdanovich, R.; Yermak, I. In vitro and ex vivo studies of antioxidant activity of carrageenans, sulfated polysaccharides from red algae. Bull. Exp. Biol. Med. 2011, 150, 426-428. [CrossRef] [PubMed]

80. Yuan, H.; Song, J.; Zhang, W.; Li, X.; Li, N.; Gao, X. Antioxidant activity and cytoprotective effect of K-carrageenan oligosaccharides and their different derivatives. Bioorganic Med. Chem. Lett. 2006, 16, 1329-1334. [CrossRef] 
81. Sun, Y.; Yang, B.; Wu, Y.; Liu, Y.; Gu, X.; Zhang, H.; Wang, C.; Cao, H.; Huang, L.; Wang, Z. Structural characterization and antioxidant activities of $\mathrm{K}$-carrageenan oligosaccharides degraded by different methods. Food Chem. 2015, 178, 311-318. [CrossRef] [PubMed]

82. Thevanayagam, H.; Mohamed, S.M.; Chu, W.-L. Assessment of UVB-photoprotective and antioxidative activities of carrageenan in keratinocytes. J. Appl. Phycol. 2014, 26, 1813-1821. [CrossRef]

83. Shojaee-Aliabadi, S.; Hosseini, H.; Mohammadifar, M.A.; Mohammadi, A.; Ghasemlou, M.; Ojagh, S.M.; Hosseini, S.M.; Khaksar, R. Characterization of antioxidant-antimicrobial $\mathrm{k}$-carrageenan films containing Satureja hortensis essential oil. Int. J. Biol. Macromol. 2013, 52, 116-124. [CrossRef]

84. Chen, L.; Hu, J.Y.; Wang, S.Q. The role of antioxidants in photoprotection: A critical review. J. Am. Acad. Dermatol. 2012, 67, 1013-1024. [CrossRef]

85. Nantel, F.; Denis, D.; Gordon, R.; Northey, A.; Cirino, M.; Metters, K.M.; Chan, C.C. Distribution and regulation of cyclooxygenase 2 in carrageenan induced inflammation. Br. J. Pharmacol. 1999, 128, 853-859. [CrossRef] [PubMed]

86. Tripp, C.S.; Blomme, E.A.; Chinn, K.S.; Hardy, M.M.; LaCelle, P.; Pentland, A.P. Epidermal COX-2 induction following ultraviolet irradiation: Suggested mechanism for the role of COX-2 inhibition in photoprotection. J. Investig. Dermatol. 2003, 121, 853-861. [CrossRef]

87. Purwaningsih, S.; Salamah, E.; Adnin, M.N. Efek fotoprotektif krim tabir surya dengan penambahan karaginan dan buah bakau hitam (Rhizopora mucronata Lamk.). J. Ilmu Dan Teknol. Kelaut. Trop. 2015, 7, 1-14.

88. Abraham, R.E.; Su, P.; Puri, M.; Raston, C.L.; Zhang, W. Optimisation of biorefinery production of alginate, fucoidan and laminarin from brown seaweed Durvillaea potatorum. Algal Res. 2019, 38, 101389. [CrossRef]

89. Ozanne, H.; Toumi, H.; Roubinet, B.; Landemarre, L.; Lespessailles, E.; Daniellou, R.; Cesaro, A. Laminarin Effects, a $\beta$-(1,3)Glucan, on Skin Cell Inflammation and Oxidation. Cosmetics 2020, 7, 66. [CrossRef]

90. Cuong, D.X. Laminarin (Beta-glucan) of Brown Algae Sargassum mcclurei: Extraction, Antioxidant Activity, Lipoxygenase Inhibition Activity, and Physicochemistry Properties. World J. Food Sci. Technol. 2020, 4, 31. [CrossRef]

91. Sellimi, S.; Maalej, H.; Rekik, D.M.; Benslima, A.; Ksouda, G.; Hamdi, M.; Sahnoun, Z.; Li, S.; Nasri, M.; Hajji, M. Antioxidant, antibacterial and in vivo wound healing properties of laminaran purified from Cystoseira barbata seaweed. Int. J. Biol. Macromol. 2018, 119, 633-644. [CrossRef]

92. Li, J.; Xie, L.; Qin, Y.; Liang, W.-H.; Mo, M.-Q.; Liu, S.-L.; Liang, F.; Wang, Y.; Tan, W.; Liang, Y. Effect of laminarin polysaccharide on activity of matrix metalloproteinase in photoaging skin. Zhongguo Zhong Yao Za Zhi 2013, 38, $2370-2373$.

93. Ahn, J.H.; Kim, D.W.; Park, C.W.; Kim, B.; Sim, H.; Kim, H.S.; Lee, T.-K.; Lee, J.-C.; Yang, G.E.; Her, Y. Laminarin Attenuates Ultraviolet-Induced Skin Damage by Reducing Superoxide Anion Levels and Increasing Endogenous Antioxidants in the Dorsal Skin of Mice. Mar. Drugs 2020, 18, 345. [CrossRef]

94. Rajauria, G.; Ravindran, R.; Garcia-Vaquero, M.; Rai, D.K.; Sweeney, T.; O’Doherty, J. Molecular characteristics and antioxidant activity of laminarin extracted from the seaweed species Laminaria hyperborea, using hydrothermal-assisted extraction and a multi-step purification procedure. Food Hydrocoll. 2021, 112, 106332. [CrossRef]

95. Choi, J.-I.; Kim, H.-J.; Lee, J.-W. Structural feature and antioxidant activity of low molecular weight laminarin degraded by gamma irradiation. Food Chem. 2011, 129, 520-523. [CrossRef]

96. Choi, J.-I.; Kim, H.J.; Kim, J.H.; Lee, J.W. Enhanced biological activities of laminarin degraded by gamma-ray irradiation. J. Food Biochem. 2012, 36, 465-469. [CrossRef]

97. Kadam, S.U.; O’Donnell, C.P.; Rai, D.K.; Hossain, M.B.; Burgess, C.M.; Walsh, D.; Tiwari, B.K. Laminarin from Irish Brown Seaweeds Ascophyllum nodosum and Laminaria hyperborea: Ultrasound Assisted Extraction, Characterization and Bioactivity. Mar. Drugs 2015, 13, 4270-4280. [CrossRef]

98. Fernandes-Negreiros, M.M.; Batista, L.A.N.C.; Silva Viana, R.L.; Araujo Sabry, D.; Paiva, A.A.O.; Paiva, W.S.; Machado, R.I.A.; de Sousa Junior, F.L.; de Lima Pontes, D.; de Oliveira Vitoriano, J.; et al. Gallic Acid-Laminarin Conjugate Is a Better Antioxidant than Sulfated or Carboxylated Laminarin. Antioxidants 2020, 9, 1192. [CrossRef] [PubMed]

99. Koivikko, R.; Loponen, J.; Honkanen, T.; Jormalainen, V. Contents of soluble, cell-wall-bound and exuded phlorotannins in the brown alga Fucus vesiculosus, with implications on their ecological functions. J. Chem. Ecol. 2005, 31, 195-212. [CrossRef] [PubMed]

100. Lopes, G.; Sousa, C.; Silva, L.R.; Pinto, E.; Andrade, P.B.; Bernardo, J.; Mouga, T.; Valentão, P. Can phlorotannins purified extracts constitute a novel pharmacological alternative for microbial infections with associated inflammatory conditions? PLoS ONE 2012, 7, e31145. [CrossRef]

101. Ko, S.-C.; Cha, S.-H.; Heo, S.-J.; Lee, S.-H.; Kang, S.-M.; Jeon, Y.-J. Protective effect of Ecklonia cava on UVB-induced oxidative stress: In vitro and in vivo zebrafish model. J. Appl. Phycol. 2011, 23, 697-708. [CrossRef]

102. Milanović, Ž.; Tošović, J.; Marković, S.; Marković, Z. Comparison of the scavenging capacities of phloroglucinol and 2, 4 , 6-trihydroxypyridine towards HO' radical: A computational study. RSC Adv. 2020, 10, 43262-43272. [CrossRef]

103. Joe, M.-J.; Kim, S.-N.; Choi, H.-Y.; Shin, W.-S.; Park, G.-M.; Kang, D.-W.; Kim, Y.K. The inhibitory effects of eckol and dieckol from Ecklonia stolonifera on the expression of matrix metalloproteinase-1 in human dermal fibroblasts. Biol. Pharm. Bull. 2006, 29, 1735-1739. [CrossRef]

104. Lee, J.-w.; Seok, J.K.; Boo, Y.C. Ecklonia cava extract and dieckol attenuate cellular lipid peroxidation in keratinocytes exposed to PM10. Evid. Based Complementary Altern. Med. 2018, 2018, 1-12. [CrossRef] [PubMed] 
105. Ha, J.W.; Song, H.; Hong, S.S.; Boo, Y.C. Marine alga ecklonia cava extract and dieckol attenuate prostaglandin E2 production in HaCaT keratinocytes exposed to airborne particulate matter. Antioxidants 2019, 8, 190. [CrossRef]

106. Wang, L.; Lee, W.; Jayawardena, T.U.; Cha, S.-H.; Jeon, Y.-J. Dieckol, an algae-derived phenolic compound, suppresses airborne particulate matter-induced skin aging by inhibiting the expressions of pro-inflammatory cytokines and matrix metalloproteinases through regulating NF-кB, AP-1, and MAPKs signaling pathways. Food Chem. Toxicol. 2020, 146, 111823. [CrossRef] [PubMed]

107. Kim, K.C.; Piao, M.J.; Cho, S.J.; Lee, N.H.; Hyun, J.W. Phloroglucinol protects human keratinocytes from ultraviolet B radiation by attenuating oxidative stress. Photodermatol. Photoimmunol. Photomed. 2012, 28, 322-331. [CrossRef]

108. Piao, M.J.; Ahn, M.J.; Kang, K.A.; Kim, K.C.; Zheng, J.; Yao, C.W.; Cha, J.W.; Hyun, C.L.; Kang, H.K.; Lee, N.H. Phloroglucinol inhibits ultraviolet B radiation-induced oxidative stress in the mouse skin. Int. J. Radiat. Biol. 2014, 90, 928-935. [CrossRef] [PubMed]

109. Im, A.R.; Nam, K.W.; Hyun, J.W.; Chae, S. Phloroglucinol reduces photodamage in hairless mice via matrix metalloproteinase activity through MAPK pathway. Photochem. Photobiol. 2016, 92, 173-179. [CrossRef]

110. Piao, M.J.; Ahn, M.J.; Kang, K.A.; Kim, K.C.; Cha, J.W.; Lee, N.H.; Hyun, J.W. Phloroglucinol enhances the repair of UVB radiation-induced DNA damage via promotion of the nucleotide excision repair system in vitro and in vivo. DNA Repair 2015, 28, 131-138. [CrossRef] [PubMed]

111. Park, C.; Cha, H.-J.; Hong, S.H.; Kim, G.-Y.; Kim, S.; Kim, H.-S.; Kim, B.W.; Jeon, Y.-J.; Choi, Y.H. Protective effect of phloroglucinol on oxidative stress-induced DNA damage and apoptosis through activation of the Nrf2/HO-1 signaling pathway in HaCaT human keratinocytes. Mar. Drugs 2019, 17, 225. [CrossRef]

112. Kang, K.A.; Zhang, R.; Piao, M.J.; Ko, D.O.; Wang, Z.H.; Lee, K.; Kim, B.J.; Shin, T.; Park, J.W.; Lee, N.H. Inhibitory effects of triphlorethol-A on MMP-1 induced by oxidative stress in human keratinocytes via ERK and AP-1 inhibition. J. Toxicol. Environ. HealthPart A 2008, 71, 992-999. [CrossRef] [PubMed]

113. Piao, M.J.; Zhang, R.; Lee, N.H.; Hyun, J.W. Protective effect of triphlorethol-A against ultraviolet B-mediated damage of human keratinocytes. J. Photochem. Photobiol. B Biol. 2012, 106, 74-80. [CrossRef] [PubMed]

114. Piao, M.J.; Kumara, M.H.S.R.; Kim, K.C.; Kang, K.A.; Kang, H.K.; Lee, N.H.; Hyun, J.W. Diphlorethohydroxycarmalol suppresses ultraviolet B-induced matrix metalloproteinases via inhibition of JNK and ERK signaling in human keratinocytes. Biomol. Ther. 2015, 23, 557. [CrossRef]

115. Wang, L.; Kim, H.S.; Je, J.-G.; Oh, J.Y.; Kim, Y.-S.; Cha, S.-H.; Jeon, Y.-J. Protective effect of diphlorethohydroxycarmalol isolated from Ishige okamurae against particulate matter-induced skin damage by regulation of NF- $\mathrm{B}, \mathrm{AP}-1$, and MAPKs signaling pathways in vitro in human dermal fibroblasts. Molecules 2020, 25, 1055. [CrossRef]

116. Wang, L.; Kim, H.S.; Oh, J.Y.; Je, J.G.; Jeon, Y.-J.; Ryu, B. Protective effect of diphlorethohydroxycarmalol isolated from Ishige okamurae against UVB-induced damage in vitro in human dermal fibroblasts and in vivo in zebrafish. Food Chem. Toxicol. 2020, 136, 110963. [CrossRef] [PubMed]

117. Kim, K.C.; Piao, M.J.; Zheng, J.; Yao, C.W.; Cha, J.W.; Kumara, M.H.S.R.; Han, X.; Kang, H.K.; Lee, N.H.; Hyun, J.W. Fucodiphlorethol $\mathrm{G}$ purified from Ecklonia cava suppresses ultraviolet B radiation-induced oxidative stress and cellular damage. Biomol. Ther. 2014, 22, 301. [CrossRef] [PubMed]

118. Ham, Y.-M.; Baik, J.-S.; Hyun, J.-W.; Lee, N.-H. Isolation of a new phlorotannin, fucodiphlorethol G, from a brown alga Ecklonia cava. Bull. Korean Chem. Soc. 2007, 28, 1595-1597.

119. Baxter, H.; Harborne, J.B.; Moss, G.P. Phytochemical Dictionary: A Handbook of Bioactive Compounds from Plants; CRC Press: Boca Raton, FL, USA, 1998.

120. Miyamoto, K.T.; Komatsu, M.; Ikeda, H. Discovery of gene cluster for mycosporine-like amino acid biosynthesis from Actinomycetales microorganisms and production of a novel mycosporine-like amino acid by heterologous expression. Appl. Environ. Microbiol. 2014, 80, 5028-5036. [CrossRef] [PubMed]

121. Wada, N.; Sakamoto, T.; Matsugo, S. Mycosporine-like amino acids and their derivatives as natural antioxidants. Antioxidants 2015, 4, 603-646. [CrossRef]

122. Karsten, U.; Friedl, T.; Schumann, R.; Hoyer, K.; Lembcke, S. Mycosporine-like amino acids and phylogenies in green algae: Prasiola and its relatives from the trebouxiophyceae (chlorophyta) 1. J. Phycol. 2005, 41, 557-566. [CrossRef]

123. Bhatia, S.; Garg, A.; Sharma, K.; Kumar, S.; Sharma, A.; Purohit, A.P. Mycosporine and mycosporine-like amino acids: A paramount tool against ultra violet irradiation. Pharm. Rev. 2011, 5, 138-146. [CrossRef]

124. Singh, D.K.; Pathak, J.; Pandey, A.; Singh, V.; Ahmed, H.; Rajneesh; Kumar, D.; Sinha, R.P. Chapter 15-Ultraviolet-screening compound mycosporine-like amino acids in cyanobacteria: Biosynthesis, functions, and applications. In Advances in Cyanobacterial Biology; Singh, P.K., Kumar, A., Singh, V.K., Shrivastava, A.K., Eds.; Academic Press: Cambridge, MA, USA, 2020 ; pp. $219-233$.

125. Kim, S.Y.; Cho, W.K.; Kim, H.-I.; Paek, S.H.; Jang, S.J.; Jo, Y.; Choi, H.; Lee, J.H.; Moh, S.H. Transcriptome Profiling of Human Follicle Dermal Papilla Cells in response to Porphyra-334 Treatment by RNA-Seq. Evid. Based Complementary Altern. Med. 2021, 2021, 6637513. [CrossRef] [PubMed]

126. Sun, Y.; Zhang, N.; Zhou, J.; Dong, S.; Zhang, X.; Guo, L.; Guo, G. Distribution, contents, and types of mycosporine-like amino acids (MAAs) in marine macroalgae and a database for MAAs based on these characteristics. Mar. Drugs 2020, 18, 43. [CrossRef] [PubMed]

127. De la Coba, F.; Aguilera, J.; Figueroa, F.L.; De Gálvez, M.; Herrera, E. Antioxidant activity of mycosporine-like amino acids isolated from three red macroalgae and one marine lichen. J. Appl. Phycol. 2009, 21, 161-169. [CrossRef] 
128. Hartmann, A.; Becker, K.; Karsten, U.; Remias, D.; Ganzera, M. Analysis of mycosporine-like amino acids in selected algae and cyanobacteria by hydrophilic interaction liquid chromatography and a novel MAA from the red alga Catenella repens. Mar. Drugs 2015, 13, 6291-6305. [CrossRef]

129. Álvarez-Gómez, F.; Korbee, N.; Casas-Arrojo, V.; Abdala-Díaz, R.T.; Figueroa, F.L. UV photoprotection, cytotoxicity and immunology capacity of red algae extracts. Molecules 2019, 24, 341. [CrossRef]

130. Torres, P.; Nagai, A.; Teixeira, D.I.A.; Marinho-Soriano, E.; Chow, F.; dos Santos, D.Y. Brazilian native species of Gracilaria (Gracilariales, Rhodophyta) as a source of valuable compounds and as nutritional supplements. J. Appl. Phycol. 2019, 31, 3163-3173. [CrossRef]

131. Nishida, Y.; Kumagai, Y.; Michiba, S.; Yasui, H.; Kishimura, H. Efficient extraction and antioxidant capacity of mycosporine-like amino acids from red alga Dulse Palmaria palmata in Japan. Mar. Drugs 2020, 18, 502. [CrossRef] [PubMed]

132. Ryu, J.; Park, S.-J.; Kim, I.-H.; Choi, Y.H.; Nam, T.-J. Protective effect of porphyra-334 on UVA-induced photoaging in human skin fibroblasts. Int. J. Mol. Med. 2014, 34, 796-803. [CrossRef] [PubMed]

133. Athukorala, Y.; Trang, S.; Kwok, C.; Yuan, Y.V. Antiproliferative and antioxidant activities and mycosporine-like amino acid profiles of wild-harvested and cultivated edible Canadian marine red macroalgae. Molecules 2016, 21, 119. [CrossRef] [PubMed]

134. Suh, S.-S.; Oh, S.K.; Lee, S.G.; Kim, I.-C.; Kim, S. Porphyra-334, a mycosporine-like amino acid, attenuates UV-induced apoptosis in HaCaT cells. Acta Pharm. 2017, 67, 257-264. [CrossRef]

135. Gacesa, R.; Lawrence, K.P.; Georgakopoulos, N.D.; Yabe, K.; Dunlap, W.C.; Barlow, D.J.; Wells, G.; Young, A.R.; Long, P.F. The mycosporine-like amino acids porphyra-334 and shinorine are antioxidants and direct antagonists of Keap1-Nrf2 binding. Biochimie 2018, 154, 35-44. [CrossRef]

136. Ying, R.; Zhang, Z.; Zhu, H.; Li, B.; Hou, H. The protective effect of mycosporine-like amino acids (MAAs) from Porphyra yezoensis in a mouse model of UV irradiation-induced photoaging. Mar. Drugs 2019, 17, 470. [CrossRef]

137. Cho, M.J.; Jung, H.S.; Song, M.Y.; Seo, H.H.; Kulkarni, A.; Suh, S.S.; Lee, T.K.; Moh, S.H. Effect of sun screen utilizing Porphyra-334 derived from ocean algae for skin protection. J. Korea Acad. Ind. Coop. Soc. 2014, 15, 4272-4278.

138. Pangestuti, R.; Bak, S.S.; Kim, S.K. Attenuation of pro-inflammatory mediators in LPS-stimulated BV2 microglia by chitooligosaccharides via the MAPK signaling pathway. Int. J. Biol. Macromol. 2011, 49, 599-606. [CrossRef] [PubMed]

139. Becker, K.; Hartmann, A.; Ganzera, M.; Fuchs, D.; Gostner, J.M. Immunomodulatory effects of the mycosporine-like amino acids shinorine and porphyra-334. Mar. Drugs 2016, 14, 119. [CrossRef] [PubMed]

140. Terazawa, S.; Nakano, M.; Yamamoto, A.; Imokawa, G. Mycosporine-like amino acids stimulate hyaluronan secretion by upregulating hyaluronan synthase 2 via activation of the p38/MSK1/CREB/c-Fos/AP-1 axis: MAAs stimulate the secretion of HA via HAS2. J. Biol. Chem. 2020, 295, 7274-7288. [CrossRef]

141. Rui, Y.; Zhaohui, Z.; Wenshan, S.; Bafang, L.; Hu, H. Protective effect of MAAs extracted from Porphyra tenera against UV irradiation-induced photoaging in mouse skin. J. Photochem. Photobiol. B Biol. 2019, 192, 26-33. [CrossRef] [PubMed]

142. Reilly, D.M.; Lozano, J. Skin collagen through the lifestages: Importance for skin health and beauty. Plast. Aesthetic Res. 2021, 8. [CrossRef]

143. Orfanoudaki, M.; Hartmann, A.; Alilou, M.; Gelbrich, T.; Planchenault, P.; Derbré, S.; Schinkovitz, A.; Richomme, P.; Hensel, A.; Ganzera, M. Absolute configuration of mycosporine-like amino acids, their wound healing properties and in vitro anti-aging effects. Mar. Drugs 2020, 18, 35. [CrossRef] [PubMed]

144. Suh, S.-S.; Lee, S.G.; Youn, U.J.; Han, S.J.; Kim, I.-C.; Kim, S. Comprehensive expression profiling and functional network analysis of porphyra-334, one mycosporine-like amino acid (MAA), in human keratinocyte exposed with UV-radiation. Mar. Drugs 2017, 15, 196. [CrossRef]

145. Daniel, S.; Cornelia, S.; Fred, Z. UV-A sunscreen from red algae for protection against premature skin aging. Cosmet Toilet. Manuf. Worldw. 2004, 2004, 139-143.

146. Bhatia, S.; Sharma, K.; Namdeo, A.G.; Chaugule, B.; Kavale, M.; Nanda, S. Broad-spectrum sun-protective action of Porphyra-334 derived from Porphyra vietnamensis. Pharmacogn. Res. 2010, 2, 45. [CrossRef] [PubMed]

147. de la Coba, F.; Aguilera, J.; Korbee, N.; de Gálvez, M.V.; Herrera-Ceballos, E.; Álvarez-Gómez, F.; Figueroa, F.L. UVA and UVB photoprotective capabilities of topical formulations containing mycosporine-like amino acids (MAAs) through different Biological Effective Protection Factors (BEPFs). Mar. Drugs 2019, 17, 55. [CrossRef] [PubMed]

148. Proctor, M.S.; Pazderník, M.; Jackson, P.J.; Pilný, J.; Martin, E.C.; Dickman, M.J.; Canniffe, D.P.; Johnson, M.P.; Hunter, C.N.; Sobotka, R.; et al. Xanthophyll carotenoids stabilise the association of cyanobacterial chlorophyll synthase with the LHC-like protein HliD. Biochem. J. 2020, 477, 4021-4036. [CrossRef]

149. Maoka, T. Carotenoids as natural functional pigments. J. Nat. Med. 2020, 74, 1-16. [CrossRef]

150. Heo, S.-J.; Jeon, Y.-J. Protective effect of fucoxanthin isolated from Sargassum siliquastrum on UV-B induced cell damage. J. Photochem. Photobiol. B Biol. 2009, 95, 101-107. [CrossRef]

151. Urikura, I.; Sugawara, T.; Hirata, T. Protective effect of fucoxanthin against UVB-induced skin photoaging in hairless mice. Biosci. Biotechnol. Biochem. 2011, 75, 757-760. [CrossRef] [PubMed]

152. Zheng, J.; Piao, M.J.; Keum, Y.S.; Kim, H.S.; Hyun, J.W. Fucoxanthin protects cultured human keratinocytes against oxidative stress by blocking free radicals and inhibiting apoptosis. Biomol. Ther. 2013, 21, 270. [CrossRef]

153. Zheng, J.; Piao, M.J.; Kim, K.C.; Yao, C.W.; Cha, J.W.; Hyun, J.W. Fucoxanthin enhances the level of reduced glutathione via the Nrf2-mediated pathway in human keratinocytes. Mar. Drugs 2014, 12, 4214-4230. [CrossRef] 
154. Miyashita, K.; Beppu, F.; Hosokawa, M.; Liu, X.; Wang, S. Nutraceutical characteristics of the brown seaweed carotenoid fucoxanthin. Arch. Biochem. Biophys. 2020,686, 108364. [CrossRef]

155. Rodríguez-Luna, A.; Ávila-Román, J.; González-Rodríguez, M.L.; Cózar, M.J.; Rabasco, A.M.; Motilva, V.; Talero, E. Fucoxanthincontaining cream prevents epidermal hyperplasia and UVB-induced skin erythema in mice. Mar. Drugs 2018, 16, 378. [CrossRef] [PubMed]

156. Rodríguez-Luna, A.; Ávila-Román, J.; Oliveira, H.; Motilva, V.; Talero, E. Fucoxanthin and rosmarinic acid combination has anti-inflammatory effects through regulation of NLRP3 inflammasome in UVB-exposed HaCaT keratinocytes. Mar. Drugs 2019, 17, 451. [CrossRef]

157. Wang, Z.; Man, M.-Q.; Li, T.; Elias, P.M.; Mauro, T.M. Aging-associated alterations in epidermal function and their clinical significance. Aging 2020, 12, 5551-5565. [CrossRef] [PubMed]

158. Matsui, M.; Tanaka, K.; Higashiguchi, N.; Okawa, H.; Yamada, Y.; Tanaka, K.; Taira, S.; Aoyama, T.; Takanishi, M.; Natsume, C. Protective and therapeutic effects of fucoxanthin against sunburn caused by UV irradiation. J. Pharmacol. Sci. 2016, 132, 55-64. [CrossRef] [PubMed]

159. Chung, J.H.; Eun, H.C. Angiogenesis in skin aging and photoaging. J. Dermatol. 2007, 34, 593-600. [CrossRef]

160. Chen, S.-J.; Lee, C.-J.; Lin, T.-B.; Liu, H.-J.; Huang, S.-Y.; Chen, J.-Z.; Tseng, K.-W. Inhibition of Ultraviolet B-Induced Expression of the Proinflammatory Cytokines TNF- $\alpha$ and VEGF in the Cornea by Fucoxanthin Treatment in a Rat Model. Mar. Drugs 2016, 14, 13. [CrossRef] [PubMed]

161. Spagolla Napoleão Tavares, R.; Maria-Engler, S.S.; Colepicolo, P.; Debonsi, H.M.; Schäfer-Korting, M.; Marx, U.; Gaspar, L.R.; Zoschke, C. Skin irritation testing beyond tissue viability: Fucoxanthin effects on inflammation, homeostasis, and metabolism. Pharmaceutics 2020, 12, 136. [CrossRef]

162. Gomez-Zavaglia, A.; Prieto Lage, M.A.; Jimenez-Lopez, C.; Mejuto, J.C.; Simal-Gandara, J. The Potential of Seaweeds as a Source of Functional Ingredients of Prebiotic and Antioxidant Value. Antioxidantsc 2019, 8, 406. [CrossRef]

163. Pereira, R.; Yarish, C. Mass Production of Marine Macroalgae. In Encyclopedia of Ecology; Jørgensen, S.E., Fath, B.D., Eds.; Academic Press: Oxford, UK, 2008; pp. 2236-2247.

164. García-Poza, S.; Leandro, A.; Cotas, C.; Cotas, J.; Marques, J.C.; Pereira, L.; Gonçalves, A.M. The Evolution Road of Seaweed Aquaculture: Cultivation Technologies and the Industry 4.0. Int. J. Environ. Res. Public Health 2020, 17, 6528. [CrossRef]

165. Hayashi, L.; Cantarino, S.D.J.; Critchley, A.T. Challenges to the future domestication of seaweeds as cultivated species: Understanding their physiological processes for large-scale production. In Advances in Botanical Research; Elsevier: Amsterdam, The Netherlands, 2020; Volume 95, pp. 57-83.

166. Chary, K.; Aubin, J.; Sadoul, B.; Fiandrino, A.; Covès, D.; Callier, M.D. Integrated multi-trophic aquaculture of red drum (Sciaenops ocellatus) and sea cucumber (Holothuria scabra): Assessing bioremediation and life-cycle impacts. Aquaculture 2020, 516, 734621. [CrossRef]

167. Pliego-Cortés, H.; Bedoux, G.; Boulho, R.; Taupin, L.; Freile-Pelegrín, Y.; Bourgougnon, N.; Robledo, D. Stress tolerance and photoadaptation to solar radiation in Rhodymenia pseudopalmata (Rhodophyta) through mycosporine-like amino acids, phenolic compounds, and pigments in an Integrated Multi-Trophic Aquaculture system. Algal Res. 2019, 41, 101542. [CrossRef]

168. Barceló-Villalobos, M.; Figueroa, F.L.; Korbee, N.; Álvarez-Gómez, F.; Abreu, M.H. Production of mycosporine-like amino acids from Gracilaria vermiculophylla (Rhodophyta) cultured through one year in an Integrated Multi-Trophic Aquaculture (IMTA) system. Mar. Biotechnol. 2017, 19, 246-254. [CrossRef]

169. Noori, N.; Dukkipati, R.; Kovesdy, C.P.; Sim, J.J.; Feroze, U.; Murali, S.B.; Bross, R.; Benner, D.; Kopple, J.D.; Kalantar-Zadeh, K. Dietary Omega-3 Fatty Acid, Ratio of Omega-6 to Omega-3 Intake, Inflammation, and Survival in Long-term Hemodialysis Patients. Am. J. Kidney Dis. 2011, 58, 248-256. [CrossRef] [PubMed]

170. Lourenço-Lopes, C.; Garcia-Oliveira, P.; Carpena, M.; Fraga-Corral, M.; Jimenez-Lopez, C.; Pereira, A.G.; Prieto, M.A.; SimalGandara, J. Scientific approaches on extraction, purification and stability for the commercialization of fucoxanthin recovered from brown algae. Foods 2020, 9, 1113. [CrossRef]

171. Gereniu, C.R.N.; Saravana, P.S.; Chun, B.-S. Recovery of carrageenan from Solomon Islands red seaweed using ionic liquid-assisted subcritical water extraction. Sep. Purif. Technol. 2018, 196, 309-317. [CrossRef]

172. Saravana, P.S.; Tilahun, A.; Gerenew, C.; Tri, V.D.; Kim, N.H.; Kim, G.-D.; Woo, H.-C.; Chun, B.-S. Subcritical water extraction of fucoidan from Saccharina japonica: Optimization, characterization and biological studies. J. Appl. Phycol. 2018, 30, 579-590. [CrossRef]

173. Fung, A.; Hamid, N.; Lu, J. Fucoxanthin content and antioxidant properties of Undaria pinnatifida. Food Chem. 2013, 136, 1055-1062. [CrossRef] [PubMed]

174. Roh, M.K.; Uddin, M.S.; Chun, B.S. Extraction of fucoxanthin and polyphenol from Undaria pinnatifida using supercritical carbon dioxide with co-solvent. Biotechnol. Bioprocess Eng. 2008, 13, 724-729. [CrossRef]

175. Quitain, A.T.; Kai, T.; Sasaki, M.; Goto, M. Supercritical carbon dioxide extraction of fucoxanthin from Undaria pinnatifida. J. Agric. Food Chem. 2013, 61, 5792-5797. [CrossRef] [PubMed]

176. Eom, S.J.; Kim, Y.E.; Kim, J.-E.; Park, J.; Kim, Y.H.; Song, K.-M.; Lee, N.H. Production of Undaria pinnatifida sporophyll extract using pilot-scale ultrasound-assisted extraction: Extract characteristics and antioxidant and anti-inflammatory activities. Algal Res. 2020, 51, 102039. [CrossRef] 
177. Xiao, X.; Si, X.; Yuan, Z.; Xu, X.; Li, G. Isolation of fucoxanthin from edible brown algae by microwave-assisted extraction coupled with high-speed countercurrent chromatography. J. Sep. Sci. 2012, 35, 2313-2317. [CrossRef] [PubMed]

178. Hu, Y.; Zeng, H.; Huang, J.; Jiang, L.; Chen, J.; Zeng, Q. Traditional Asian herbs in skin whitening: The current development and limitations. Front. Pharmacol. 2020, 11, 982. [CrossRef]

179. Gelyma Helionori-Natural Sun Protection Thanks to Marine UVA Filters. Available online: http://www.gelyma.com/helionori. html (accessed on 7 February 2021).

180. Mibellebiochemistry Helioguard ${ }^{\mathrm{TM}} 365$ A Natural UV-Screening Active to Protect Against Photo-Aging. Available online: https:/ / mibellebiochemistry.com/helioguardtm-365 (accessed on 7 February 2021).

181. Laboratoires-biarritz Suncare Organic-Alga Maris ${ }^{\circledR}$. Available online: https://www.laboratoires-biarritz.com/fr/ (accessed on 7 February 2021).

182. Marinova Marinova Product Portofolio. Available online: https://www.marinova.com.au/product-portfolio/ (accessed on 7 February 2021). 